\title{
ORIGINAL ARTICLE Role for Prdx1 as a specific sensor in redox-regulated senescence in breast cancer
}

\author{
B Turner-Ivey ${ }^{1}$, Y Manevich ${ }^{2}$, J Schulte ${ }^{2}$, E Kistner-Griffin ${ }^{3}$, A Jezierska-Drutel ${ }^{2}$, Y Liu ${ }^{4}$ and CA Neumann ${ }^{2,5,6}$
}

\begin{abstract}
Recent studies suggest that Peroxiredoxin 1 ( $\mathrm{Prdx} 1$ ), in addition to its known $\mathrm{H}_{2} \mathrm{O}_{2}$-scavenging function, mediates cell signaling through redox-specific protein-protein interactions. Our data illustrate how Prdx1 specifically coordinates p38MAPK-induced signaling through regulating p38MAPK $\alpha$ phosphatases in an $\mathrm{H}_{2} \mathrm{O}_{2}$ dose-dependent manner. MAPK phosphatases (MKP-1 and/or MKP-5), which are known to dephosphorylate and deactivate the senescence-inducing MAPK p38 $\alpha$, belong to a group of redoxsensitive phosphatases (protein tyrosine phosphatases) characterized by a low pKa cysteine in their active sites. We found that Prdx1 bound to both MKP-1 and MKP-5, but dissociated from MKP-1 when the Prdx1 peroxidatic cysteine Cys52 was over-oxidized to sulfonic acid, which in turn resulted in MKP-1 oxidation-induced oligomerization and inactivity toward p38MAPK $\alpha$. Conversely, over-oxidation of Prdx1-Cys52 was enhancing in the Prdx1:MKP-5 complex with increasing amounts of $\mathrm{H}_{2} \mathrm{O}_{2}$ concentrations and correlated with a protection from oxidation-induced oligomerization and inactivation of MKP-5 so that activation toward p38MAPK was maintained. Further examination of this Prdx1-specific mechanism in a model of reactive oxygen species-induced senescence of human breast epithelial cells revealed the specific activation of MKP-5, resulting in decreased p38MAPK $\alpha$ activity. Taken together, our data suggest that Prdx1 orchestrates redox signaling in an $\mathrm{H}_{2} \mathrm{O}_{2}$ dose-dependent manner through the oxidation status of its peroxidatic cysteine Cys52.
\end{abstract}

Oncogene (2013) 32, 5302-5314; doi:10.1038/onc.2012.624; published online 21 January 2013

Keywords: redox signaling; peroxiredoxin; senescence; oxidative stress; protein tyrosine phosphatases; p38MAPK

\section{INTRODUCTION}

A role for reactive oxygen species (ROS) in cell signaling has long been accepted, however, detailed evidence demonstrating their specific impact on signaling events is still lacking. Recent studies from our laboratory and others suggest that one possible mechanism is via protein oxidation, thereby modifying protein function. Cellular ROS impacts signaling through their localized accumulation, if we consider ROS as by-products of the electron transport chain in the mitochondria or activation of NADPH oxidases. This requires the local and timely availability of ROSscavenging enzymes at the time of ROS build-up, to protect proteins from oxidation-induced modifications affecting cell signaling. A new class of peroxidases, the peroxiredoxins ( $\operatorname{rrdxs}$ ), offer such flexibility since they are not as compartmentalized in the cell as catalase. Prdxs (Prdx1-6) are a superfamily of small nonseleno peroxidases (22-27 kDa) currently known to comprise six mammalian isoforms. Prdxs 1-5 are classified as 2-Cys Prdxs and Prdx6 as 1-Cys Prdx. ${ }^{1}$ In typical 2-Cys Prdxs, like the mammalian $\operatorname{Prdx1}$, the peroxidatic cysteine (Cys52 in $\mathrm{Prdx} 1$ ) reduces $\mathrm{H}_{2} \mathrm{O}_{2}$ to $\mathrm{H}_{2} \mathrm{O}$ and becomes oxidized to sulfenic acid. The resolving cysteine (Cys173 in Prdx1) of another subunit reacts with the sulfenic acid to form an intramolecular disulfide, which can be reduced by thioredoxin (Trx). Trx is then reduced by NADPH-dependent Trx reductase. Over-oxidation of Prdx1's Cys52 renders the peroxidase inactive. ${ }^{2-4}$ Recent evidence suggests that $\operatorname{Prdx} 1$ may be a 'fine tuner' of cellular $\mathrm{H}_{2} \mathrm{O}_{2}$ signaling by regulating the activity of binding partners ${ }^{4}$ such as $\mathrm{JNK}^{5}$ c-Abl kinase ${ }^{6}$ and as we have recently shown, the phosphatase PTEN. ${ }^{7}$

We demonstrate that $\operatorname{Prdx} 1$ regulates p38MAPK $\alpha$ activity in senescence signaling by differentially modulating the activity of two p38MAPK $\alpha$ phosphatases, MAP kinase phosphatase 1 (MKP-1) and MKP-5. P38MAPK $\alpha$, an essential mediator of senescence, is activated by several different MAPK kinases (MAP2K). Among these, ASK1 (apoptosis signal-regulating kinase 1) and MAPK kinases (MKKs), such as MKK3, MKK4 and MKK6, mediate ROS-induced senescence by activating p38MAPK $\alpha$ through phosphorylation on Thr180 and Tyr182. ${ }^{9}$ P38MAPK $\alpha$ is dephosphorylated and inactivated predominantly by MKP-1 and MKP-5. ${ }^{10}$ Like PTEN, MKPs belong to the class of protein tyrosine phosphatases characterized by a catalytic low $\mathrm{p} K_{\mathrm{a}}$ cysteine residue $\left(\mathrm{pK}_{\mathrm{a}}\right.$ 4.7-5.4) located within a conserved motif of its active site, which when oxidized abolishes its nucleophilic properties. This process renders the phosphatase inactive, ${ }^{11,12}$ leading to disulfidebased oligomeric structures reducible by $\beta$-mercaptoethanol. ${ }^{13}$ We have shown that Prdx1 binding to PTEN is essential for the protection of PTEN lipid phosphatase activity from oxidationinduced inactivation in oncogenic Akt signaling, ${ }^{7}$ suggesting a role for Prdx1 in regulating oxidation-sensitive phosphatases.

In our present study, we are extending the role for Prdx1 as a specific regulator of redox signaling. While $\operatorname{Prdx} 1$ bound to both

${ }^{1}$ Department of Pathology, Medical University of South Carolina, Charleston, SC, USA; ${ }^{2}$ Department of Cell and Molecular Pharmacology and Experimental Therapeutics Medical Medical University of South Carolina, Charleston, SC, USA; ${ }^{3}$ Department of Biostatistics and Epidemiology, Medical University of South Carolina, Charleston, SC, USA; ${ }^{4}$ Department of Pediatrics, The Research Institute at Nationwide Children's Hospital, Columbus, OH, USA; ${ }^{5}$ Department of Pharmacology and Chemical Biology, University of Pittsburgh, Pittsburgh, PA, USA and ${ }^{6}$ Magee-Womens Research Institute, UPCl, Pittsburgh, PA, USA. Correspondence: Dr C Neumann, Department of Pharmacology and Chemical Biology, University of Pittsburgh, E1340 Thomas E. Starzl Biomedical Science Tower 200 Lothrop Street, Pittsburgh, PA 15261, USA or Magee-Womens Research Institute, UPCI, 204 Craft Avenue, Pittsburgh, PA 15213, USA.

E-mail: neumannc@upmc.edu

Received 16 March 2012; revised 21 November 2012; accepted 30 November 2012; published online 21 January 2013 
MKP-1 and MKP-5, it only dissociated from MKP-1 under $\mathrm{H}_{2} \mathrm{O}_{2}$ induced stress, thereby allowing $\mathrm{H}_{2} \mathrm{O}_{2}$-induced oligomerization of MKP-1 and loss of its activity toward p38MAPK $\alpha$. Prdx 1 protected MKP-5 from oxidation-induced inactivation at high concentrations of $\mathrm{H}_{2} \mathrm{O}_{2}$, promoting MKP-5 activity toward p38MAPK $\alpha$. Unexpectedly, binding of Prdx1 to MKP-1 and MKP-5 seemed regulated by over-oxidation of Prdx1's peroxidatic cysteine Cys52: while Prdx1Cys52-SO3 did not bind to MKP-1, it was enhanced with MKP-5 under increasing oxidative stress. This redox-specific regulation was especially relevant in p38MAPK $\alpha$-mediated senescence in human malignant breast epithelial cells (MCF-7), whereas Prdx1 only promoted the activity of MKP-5, thereby preventing p38MAPK $\alpha$-mediated senescence.

\section{RESULTS}

Lack of Prdx1 promotes senescence and p38 MAPK activation in murine fibroblasts

Murine embryonic fibroblast (MEFs) isolated from $\operatorname{Prd} \times 1^{-1-}$ embryos $^{14}$ undergoing the $3 \mathrm{~T} 3$ protocol $^{15}$ did not gain exponential growth in the first several months compared with $\operatorname{Prd} \times 1^{+/+}$MEFs (Supplementary Figure S1). In addition, plotting cell number versus passage number showed that $\operatorname{Prdx} 1^{-}-{ }^{-}$MEFs enter senescence and crisis at passage 5-7, whereas $\operatorname{Prdx} 1^{+/+}$ MEFs divided more frequently before entering senescence at passages 12-15 (Figure 1a). We therefore sought to investigate if Prdx1 regulates cellular senescence. First, we analyzed MEFs undergoing processes of spontaneous immortalization induced by passaging for signs of senescence. $\operatorname{Prdx} 1^{-1-}$ MEFs rapidly manifested a senescent morphology and exhibited positive blue staining for senescence-associated $\beta$-galactosidase $\left(\mathrm{SA}-\beta \mathrm{gal}{ }^{+}\right.$) activity. At passages $3-7, \operatorname{Prdx} 1^{-1-}$ MEFs contained 2- to 3-fold more SA- $\beta$ gal ${ }^{+}$cells compared with $\operatorname{Prdx} 1^{+/+}$MEFs (Figure 1b). Additionally, non-immortalized, primary MEFs lacking Prdx1 showed increased p53 expression and phosphorylation on Serine-15 after treatment with $\mathrm{H}_{2} \mathrm{O}_{2}$ for $8 \mathrm{~h}$ when compared with $\operatorname{Prd} \times 1^{+/+}$MEFs (Figure 1c). Since p38MAPK $\alpha$ is a major player in stress-induced senescence signaling, ${ }^{9,16}$ we investigated if $\operatorname{Prdx} 1$ regulates p38MAPK $\alpha$ activity. We treated MEFs described above with the p38MAPK $\alpha$ inhibitor SB203580 and observed that the accelerated senescence in $\operatorname{Prdx} 1^{-1-}$ MEFs is dependent on p38MAPK $\alpha$ activity. Shown in Figure $1 d$, the percent of SA- $\beta g^{+}{ }^{+}$ cells was significantly reduced for $\operatorname{Prdx} 1^{-/-}$MEFs in the presence of $6 \mu \mathrm{m}$ SB203580. Prdx $1^{+/+}$MEFs also demonstrated a significant decrease in SA- $\beta \mathrm{gal}^{+}$cells at the lower dose of $3 \mu \mathrm{m}$ SB203580. In support of this, $\operatorname{Prdx} 1^{-/-}$MEFs stimulated either with increasing amounts of $\mathrm{H}_{2} \mathrm{O}_{2}$ or platelet-derived growth factor (PDGF) showed higher levels of p38MAPK $\alpha$ phosphorylation, as well as phosphorylation of its substrate ATF-2, compared with $\operatorname{Prdx} 1^{+/+}$MEFs (Figures 1e and g).

Prdx1 prevents ROS-induced senescence in breast epithelial cells Little is known about p38MAPK $\alpha$ 's role in senescence of breast epithelial cells. To analyze if Prdx1 regulates p38MAPK $\alpha$-induced senescence in mammary epithelial cells in vivo, we analyzed mammary tissue from MMTV-v-H-RasV12-Prdx $1^{-/-}$and MMTV-v$\mathrm{H}-$ RasV12-Prdx $1^{+/+}$mice ( $n$ of 7 for each genotype) for SA- $\beta$ gal activity. Epithelial cells from MMTV-v-H-Ras $\operatorname{Prd} \times 1^{-/-}$mice consistently showed more SA- $\beta$ gal-positive cells compared with cells from MMTV-v-H-RasV12-Prdx $1^{+/+}$mice (Figure $2 \mathrm{a}$; Table 1). Moreover, human benign (MCF-10A) and malignant (MCF-7 and MDA-MB-231) mammary epithelial cells chronically treated with $\mathrm{H}_{2} \mathrm{O}_{2}$ revealed that Prdx1 knockdown using lentiviral shPrdx1 RNA promoted $\mathrm{H}_{2} \mathrm{O}_{2}$-induced senescence, indicated by a significant increase in the number of SA- $\beta \mathrm{gal}^{+}$-shPrdx 1 cells compared with pLKO1-EV cells. In MCF-10A shPrdx 1 cells (untreated and $\mathrm{H}_{2} \mathrm{O}_{2}$ treated) we observed a 4 - to 5 -fold increase in $\mathrm{SA}-\beta \mathrm{gal}^{+}$cells compared with MCF- $10^{\text {EV }}$ cells. In MCF-7, as well as MDA-MB-231 cells, the difference was slightly smaller (1.5- to 2.5-fold) suggesting a higher sensitivity of untransformed cells to senescence-inducing stimuli compared with transformed cells (Figure 2b; Supplementary Figures S2A-C). This also correlated with an appearance of senescence-associated cell morphology in

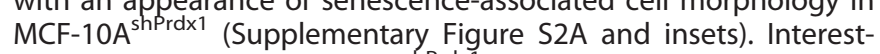
ingly, treatment of MCF-7 $7^{\text {shPrdxi }}$ cells with $\mathrm{H}_{2} \mathrm{O}_{2}$ resulted in a $>50 \%$ decrease in $\mathrm{SA}-\beta \mathrm{gal}^{+}$cells when treated with the p38MAPK $\alpha$ inhibitor SB203580 compared with non-treated cells (Figure 2c). In support of this, MCF-10A, MCF-7 as well as MDA-MB231 cells (Figure $2 \mathrm{~b}$ ) stably expressing shPrdx1 showed significantly higher levels of $\mathrm{H}_{2} \mathrm{O}_{2}$-induced phosphorylation of p38MAPK $\alpha$ compared with cells expressing pLKO1-EV only (Figures 2d-f).

Non-covalent binding of Prdx1 to MKP-1 and MKP-5 is differently modulated by $\mathrm{H}_{2} \mathrm{O}_{2}$

Prdx1 associates with PTEN, thereby protecting it from oxidationinduced inactivation and promoting its phosphatase activity. ${ }^{7}$ We therefore examined if MKP-1 and MKP-5 interact with Prdx 1. We confirmed a direct binding of Prdx1 to MKP-1 and MKP-5 by co-immunoprecipitation using recombinant proteins in vitro. To introduce higher specificity, we included Catalase as a non-Prdx1 binding protein (Figure 3a). An fluorescence resonance energy transfer (FRET)-based fluorescent analysis ${ }^{17}$ demonstrated that Prdx1's binding affinity to MKP-1 was comparable to that for PTEN $(261.0 \pm 21.2 \mathrm{nM}$ and $247.3 \pm 33.6 \mathrm{nM}$, respectively). Interestingly, Prdx1 bound to MKP-5 with an $\sim 100$-fold higher affinity $(2.4 \pm 0.2 \mathrm{nM})$ compared with MKP-1 and PTEN (Figure 3b). To address whether the binding was disulfide based, we introduced tris-(2-carboxyethyl)-phosphine (TCEP) as a reducing agent to the FRET-based fluorescent analysis and found comparable $K_{D} S$, suggesting non-covalent binding of Prdx 1 with MKP-1, MKP-5 or PTEN (Table 2). To show dynamic reversibility of protein binding, we added equal amounts of unlabeled, intact MKP-5 to MKP-5 QSY35-labeled proteins to several points of the titration curve shown in Supplementary Figure S3A, left panel ('backtitration'). This resulted in $\sim 2 \times$ decrease in Alexa546 quenching, indicative of a competitive binding of labeled and unlabeled MKP- 5 to the same binding site on Prdx1 (Supplementary Figure 3SA, right panel). In cells, we found that under $\mathrm{H}_{2} \mathrm{O}_{2}$-induced stress, MKP-1, as PTEN, ${ }^{7}$ forms fewer complexes with Prdx1, while Prdx1:MKP-5 complexes increased Analyzing co-IPs by western blotting in the absence of $\beta$-mercaptoethanol suggested that Prdx 1 may bind predominantly as a dimer to MKP-1 and MKP-5 (Figures $3 c$ and d). Since Prdx1:MKP-5 complexes appeared unaffected by $\mathrm{H}_{2} \mathrm{O}_{2}$, we analyzed IPs for Prdx1-Cys52-SO3. In cells treated with $\mathrm{H}_{2} \mathrm{O}_{2}$ doses inducing Prdx1-Cys52 over-oxidation (Figures $3 c$ and $d$, right panels), in contrast to MKP-1, Prdx1-Cys52-SO3 bound to MKP-5. To further analyze the role of $\operatorname{Prdx} 1$ catalytic cysteines in MKP complex formation, a Prdx1 mutant (Cys52/173Ser = Prdx1-Cl) was tested by co-IP. Prdx1-Cl bound to MKP-5 as Prdx1-WT did (Figure 3f). However, although Prdx1-Cl bound to MKP-1, it did not dissociate under $\mathrm{H}_{2} \mathrm{O}_{2}$ treatment in contrast to Prdx1-WT (Figure 3j), suggesting an active role for Prdx1-Cys52 in Prdx1:MKP-1 complex disruption.

Prdx1 protects MKP-5 from oxidation-induced oligomerization MKP-1 and MKP-5 have been reported to undergo oxidationinduced oligomerization, reflecting MKP-1 and MKP-5 inactivity. ${ }^{13}$ Therefore, we examined if Prdx1 influences MKP-1 or MKP-5 oligomerization under $\mathrm{H}_{2} \mathrm{O}_{2}$-induced stress. 293T cells co-expressing Prdx1 with either Flag-tagged MKP-1 or MKP-5 were treated with $\mathrm{H}_{2} \mathrm{O}_{2}$ and protein lysates run under nonreducing conditions. We found that $\mathrm{H}_{2} \mathrm{O}_{2}$-induced oligomerization of MKP-1 was not prevented by exogenous Prdx1-WT (Figure 4a), 
but was increased at lower $\mathrm{H}_{2} \mathrm{O}_{2}$ concentrations ( $\left.25 \mu \mathrm{m}\right)$. This was in contrast to MKP-5, where expression of exogenous Prdx1-WT prevented $\mathrm{H}_{2} \mathrm{O}_{2}$-induced oligomerization (Figure 4b). Interestingly, expressing $\mathrm{Prdx} 1-\mathrm{Cl}$ increased $\mathrm{H}_{2} \mathrm{O}_{2}$-induced oligomerization of MKP-5 but not of MKP-1 (Figures 4c and d). Analysis of p38MAPK $\alpha$ phosphorylation revealed that exogenous Prdx1-WT supported MKP-5-mediated p38MAPK $\alpha$ dephosphorylation, particularly at higher $\mathrm{H}_{2} \mathrm{O}_{2}$ concentrations (100 and $250 \mu \mathrm{m}$ ) in contrast to Prdx1-Cl (Figures 4f, h and j). This was in contrast to MKP-1, where co-expression with exogenous Prdx1-WT slightly increased p38MAPK $\alpha$ phosphorylation, while Prdx1-Cl decreased it (Figures $4 \mathrm{e}, \mathrm{g}$ and $\mathrm{i}$ ).

In the presence of $\mathrm{H}_{2} \mathrm{O}_{2}$ Prdx1 decreases MKP-1, but protects and enhances MKP-5 catalytic activity

To confirm that Prdx1 inhibits MKP-1 catalytic activity under $\mathrm{H}_{2} \mathrm{O}_{2-}$ induced stress, but promotes MKP-5 catalytic activity, we a

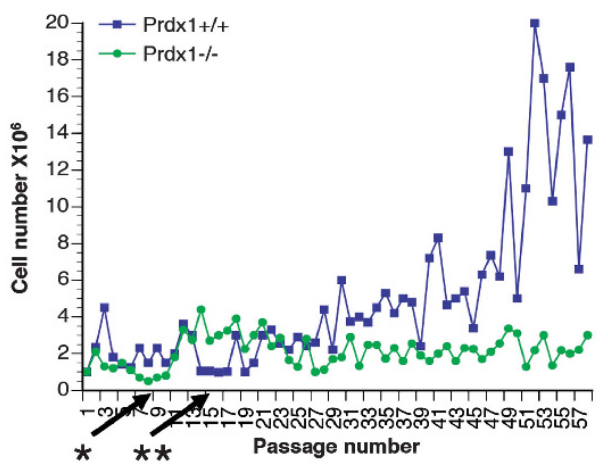

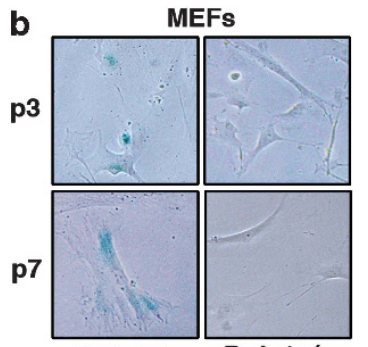

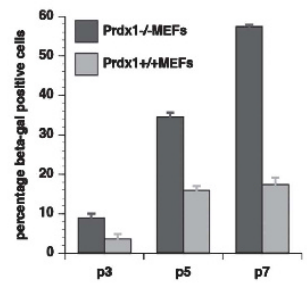

Prdx1-

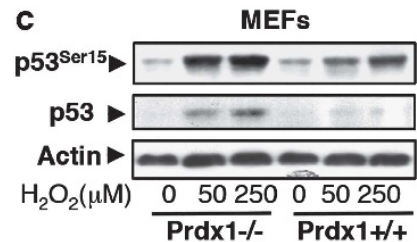

e

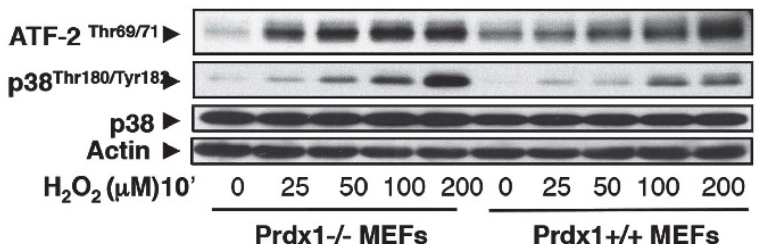

f
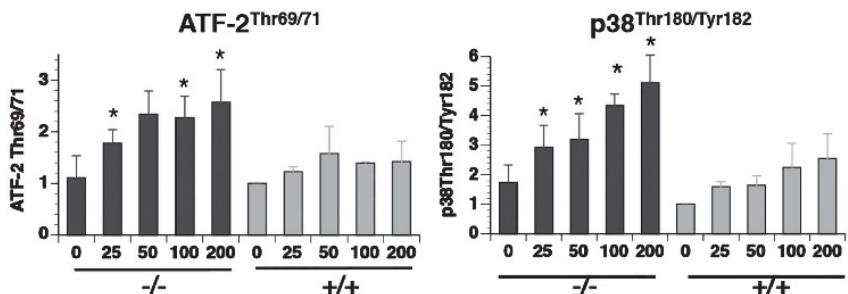

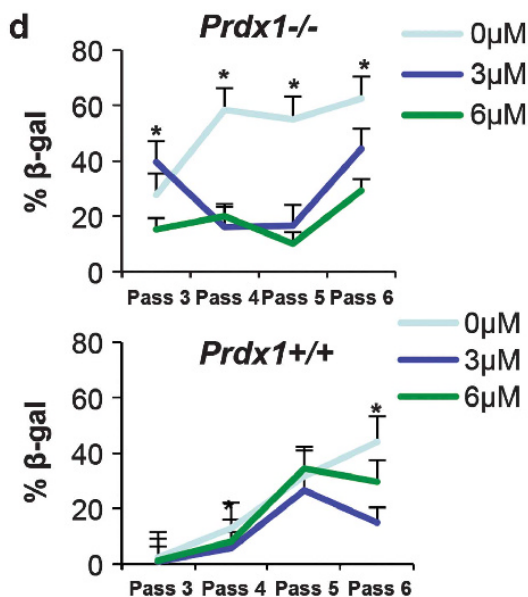

Pass 3 Pass 4 Pass 5 Pass 6
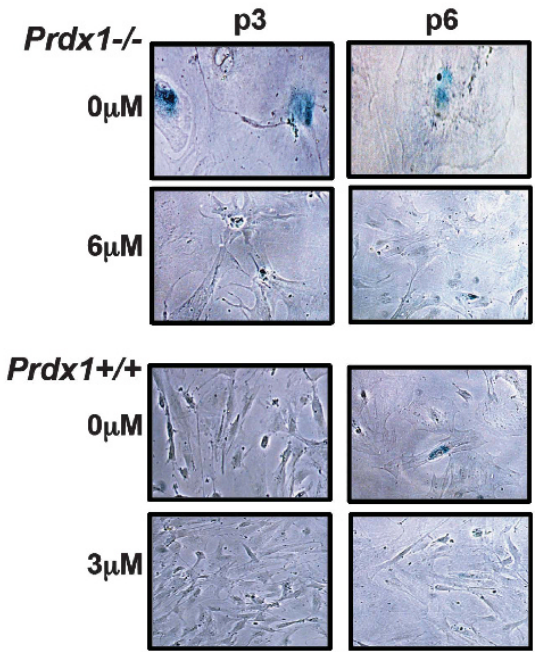
measured recombinant MKP-1 and MKP-5-mediated hydrolysis of 6,8-difluoro-4-methylumbelliferyl phosphate (DiFMUP) ${ }^{18}$ in the presence and absence of $\operatorname{Prdx} 1$ and $\mathrm{H}_{2} \mathrm{O}_{2}$. A substrate concentration of $160 \mu \mathrm{m}$ DiFMUP was determined optimal. As shown in Figure 5a, MKP-1 maintains its activity toward DiFMUP better over time compared with MKP-5. Interestingly, recombinant MKP-1 was inactivated by 50 or $150 \mu \mathrm{M}$ of $\mathrm{H}_{2} \mathrm{O}_{2}$ only when $\mathrm{Prdx} 1$ was present, but not in its absence (Figure $5 \mathrm{~b}$ ). In contrast, the $\mathrm{H}_{2} \mathrm{O}_{2}$-induced decrease in MKP-5 activity was improved significantly in the presence of Prdx1 (Figure 5c). Using a random effects model comparing the effect of Prdx1 on MKP-1 activity, the six tests of differences in treatment effects (Prdx1) over time were all statistically significant at the $\alpha=0.05$ level (Figures $5 b$ and $c$ ).

Prdx1 prevents ROS-induced senescence in MCF-7 cells through MKP-5 activity

Flag-MKP-1 WT or Cl (catalytically inactive mutant) and Flag-MKP-5 WT or $\mathrm{Cl}$ mutants were expressed in MCF-7 cells and analyzed for SA- $\beta$ gal activity after $\mathrm{H}_{2} \mathrm{O}_{2}$ treatment; these are subsequently referred to as MKP-1 or MKP-5 cells. Shown in Figure $6 a$, after $\mathrm{H}_{2} \mathrm{O}_{2}$ treatment, MKP- $5^{\mathrm{WT}}$ cells had an $80 \%$ decrease in SA- $\beta$ gal activity compared with EV cells or MKP- $5^{\mathrm{Cl}}$ cells. Interestingly, expression of both MKP-1 1 WT and MKP-1 ${ }^{\mathrm{Cl}}$ decreased senescence by $50 \%$ compared with EV cells. No quantitative difference of SA- $\beta$ gal ${ }^{+}$ was found between MKP-1 ${ }^{\text {WT }}$ and MKP-1 ${ }^{\mathrm{Cl}}$ cells. As expected, in untreated cells, expression of MKP-5 ${ }^{\mathrm{Cl}}$ and MKP-1 $\mathrm{Cl}$ increased p38MAPK $\alpha$ TGY phosphorylation, whereas expression of MKP-1 ${ }^{\text {WT }}$ and MKP-5 ${ }^{\mathrm{WT}}$ decreased it. Additionally, expression of MKP-5 $5^{\mathrm{WT}}$ decreased p38MAPK $\alpha$ phosphorylation in $\mathrm{H}_{2} \mathrm{O}_{2}$-treated cells, where MKP-1 ${ }^{\mathrm{WT}}$ did not. Interestingly, expression of MKP-5 ${ }^{\mathrm{WT}}$, and to a lesser extent MKP-5 ${ }^{\mathrm{Cl}}$, revealed a slower migrating band identified as p38MAPK $\delta$ (Figure 6b). Surprisingly, expression of MKP-1 ${ }^{\text {WT }}$ or MKP-5 ${ }^{\text {WT }}$ had very little effect on decreasing phosphorylation of JNK proteins, although expression of MKP-1 $\mathrm{Cl}$ increased JNK phosphorylation independent of $\mathrm{H}_{2} \mathrm{O}_{2}$ treatment. To analyze delayed JNK activation, we examined MCF-7 clones 2 days after $\mathrm{H}_{2} \mathrm{O}_{2}$ treatment. We found that MKP-1 ${ }^{\text {WT }}$ suppressed
JNK activity and PARP cleavage (data not shown). Finally, we investigated if the senescence observed in Figure 6a results in tumor suppression in a soft agar assay. As shown in Figure $6 \mathrm{c}$, expression of MKP-5 ${ }^{\mathrm{Cl}}$ decreased colony formation of MCF-7 ${ }^{\mathrm{EV}}$ cells by $50 \%$. Surprisingly, expressing MKP-1 ${ }^{\text {WT }}$ showed a comparable decrease, while MKP-1 ${ }^{\mathrm{Cl}}$ and MKP-5 ${ }^{\mathrm{WT}}$ expression resulted in slightly increased colony formation compared with MCF- $7^{\mathrm{EV}}$ cells.

\section{DISCUSSION}

While it is widely accepted that oxidation-induced post-translational protein modifications contribute to cell signaling, more studies are needed to fully understand how protein oxidation orchestrates signaling events. As mentioned, we have shown that Prdx1 protects the redox-sensitive PTEN from oxidation-induced inactivation. ${ }^{7}$ In the past, senescence has mainly been viewed as a tumor suppressive mechanism and more recently its therapeutic implications are investigated. Given that ROS induces senescence, and loss of Prdx1 promotes a p38MAPKphosphorylation in $\mathrm{H}_{2} \mathrm{O}_{2}$-dependent senescent phenotype, we sought to determine whether Prdx1 regulates senescence signaling specifically through the redox-sensitive p38MAPK phosphorylation in $\mathrm{H}_{2} \mathrm{O}_{2}$ phosphatases, MKP-1 and MKP-5.

\section{A role for Prdx1 in senescence}

Loss of Prdx1 accelerated the processes of senescence in MEFs (Figures $1 \mathrm{a}$ and $\mathrm{b}$ ). This was not surprising given that a similar phenotype has been described for $\operatorname{Prdx} 2{ }^{19}$ which shares high homology with Prdx1. Thus, $\mathrm{Prdx} 1$ loss amplified $\mathrm{H}_{2} \mathrm{O}_{2}$-induced p53 Ser19 phosphorylation (Figure 1c), known to accompany persistent DNA damage. ${ }^{20}$ The latter can be found in $\operatorname{Prd} \times 1^{-1}$ $\mathrm{MEFs}^{14}$ and is believed to trigger the senescence-associated secretory phenotype. ${ }^{21}$ Our data suggest that $\mathrm{Prdx} 1$ suppresses p38MAPK phosphorylation in $\mathrm{H}_{2} \mathrm{O}_{2}$ activation in the process of spontaneous immortalization, since SB203580, an ATP competitor for the p38MAPK $\alpha / \beta$ ATP docking site and known inhibitor of ROS

Figure 1. Lack of Prdx1 promotes senescence in murine fibroblasts and mammary epithelial cells. (a) Primary Prdx $1^{-/-}$and ${ }^{+/+}$MEFs were immortalized following the 3T3 protocol. Cells were counted every 3 days and cell numbers were plotted on the $y$ axis; passages were plotted on the $\mathrm{x}$ axis. Arrows indicate senescence: cell numbers did not exceed the number of cells plated. (b) Left panel: Primary Prdx $1^{-/-}$and $\operatorname{Prdx} 1^{+1+}$ MEFs of different passages were stained for SA- $\beta$ gal activity. Right panel: Quantification of (b) (up to 4000 cells per passage and genotype were analyzed). (c) Primary Prdx $1^{-1-}$ and Prdx $1^{+1+}$ MEFs were treated with increasing doses of $\mathrm{H}_{2} \mathrm{O}_{2}$ for $8 \mathrm{~h}$ and analyzed by western blotting for phosphorylation of $\mathrm{p} 53$ on Ser 15 and p53 protein levels. (d) Primary Prdx $1^{-1-}$ and Prdx $1^{+/+} \mathrm{MEFs}$ were passaged in the absence and presence of 3 and $6 \mu \mathrm{m}$ of the p38MAPK phosphorylation in $\mathrm{H}_{2} \mathrm{O}_{2}$ inhibitor SB203580, and stained for SA- $\beta$ gal activity at passages 3-6. Representative pictures showing senescent morphology and confluency were also taken. Quantification of cells positive for SA- $\beta$ gal staining was performed; '** denotes statistical significance. P-values for Prdx $1^{-1}$ - MEFs include: 0.027 (passage $3,0 \mu \mathrm{M}$ SB203580 vs $3 \mu \mathrm{M}$ ); $0.007,0.0036$ (passage 4, $0 \mu \mathrm{m} \mathrm{SB203580}$ vs $3 \mu \mathrm{m}$, and $0 \mu \mathrm{m}$ SB203580 vs $6 \mu \mathrm{m}$, respectively); 0.000, 0.000 (passage 5, $0 \mu \mathrm{m}$ SB203580 vs $3 \mu \mathrm{m}$, and $0 \mu \mathrm{m}$ SB203580 vs $6 \mu \mathrm{m}$, respectively); and 0.022, 0.003 (passage 6, $0 \mu \mathrm{m}$ SB203580 vs $3 \mu \mathrm{m}$, and $0 \mu \mathrm{M}$ SB203580 vs $6 \mu \mathrm{m}$, respectively). For Prdx $1^{+1}$ MEFs: $0.007,0.0036$ (passage $4,0 \mu \mathrm{M} \mathrm{SB} 203580$ vs $3 \mu \mathrm{m}$, and $0 \mu \mathrm{m}$ SB203580 vs $6 \mu \mathrm{m}$, respectively), and $0.000,0.0029$ (passage $6,0 \mu \mathrm{m}$ SB203580 vs $3 \mu \mathrm{m}$, and $0 \mu \mathrm{M}$ SB203580 vs $6 \mu \mathrm{M}$, respectively). (e) Prdx $1^{-1-}$ and Prdx $1^{+}{ }^{+}+$MEFs were plated on $10 \mathrm{~cm}$ plates at $1.8 \times 10^{5}$ and serum starved for $48 \mathrm{~h}$ in $0.25 \%$ FBS. Cells were treated with increasing amounts of $\mathrm{H}_{2} \mathrm{O}_{2}(25-200 \mu \mathrm{m})$ for 10 min in serum-free medium. Following treatment, plates were washed with cold $1 \times$ PBS $(\mathrm{pH} 7.2-7.4)$ two times. Cell lysates were analyzed by SDS-PAGE and western blotting for phosphorylation of p38MAPK phosphorylation in $\mathrm{H}_{2} \mathrm{O}_{2}$ on Thr 180 and Tyr 182, phosphorylation of the p38MAPK phosphorylation in $\mathrm{H}_{2} \mathrm{O}_{2}$ substrate ATF2 on Thr 69 and 71, p38MAPK phosphorylation in $\mathrm{H}_{2} \mathrm{O}_{2}$ protein levels, and actin as loading control. (f) Quantification of three independent experiments analyzing phosphorylation of p38MAPK phosphorylation in $\mathrm{H}_{2} \mathrm{O}_{2}$ and its substrate ATF2 as described under (e). Density of western blot bands was analyzed using Image J software (http://rsbweb.nih.gov/ij/). Densities of phosphorylated p38MAPK phosphorylation in $\mathrm{H}_{2} \mathrm{O}_{2}$ and ATF-2 proteins bands were normalized to density of p38MAPK phosphorylation in $\mathrm{H}_{2} \mathrm{O}_{2}$ protein bands. Values were normalized to density of untreated WT cells as 1 . Three different sets of Prdx1 WT and KO clones were tested. ${ }^{* \prime}$ indicates statistical significance (Student's $t$-test) of KO and matching WT clones treated with $\mathrm{H}_{2} \mathrm{O}_{2}$. P-values for phosphorylation of p38MAPKphosphorylation in $\mathrm{H}_{2} \mathrm{O}_{2}$ were $0.038\left(25 \mu \mathrm{m} \mathrm{H}_{2} \mathrm{O}_{2}\right), 0.039\left(50 \mu \mathrm{M} \mathrm{H}_{2} \mathrm{O}_{2}\right), 0.008\left(100 \mu \mathrm{M} \mathrm{H} \mathrm{H}_{2} \mathrm{O}_{2}\right)$ and $0.044\left(200 \mu \mathrm{M} \mathrm{H}_{2} \mathrm{O}_{2}\right)$. P-values for phosphorylation of ATF-2 were $0.022\left(25 \mu \mathrm{M} \mathrm{H}_{2} \mathrm{O}_{2}\right), 0.037\left(100 \mu \mathrm{M} \mathrm{H}_{2} \mathrm{O}_{2}\right)$ and $0.044\left(200 \mu \mathrm{M} \mathrm{H}_{2} \mathrm{O}_{2}\right)$. (g) Prdx1 ${ }^{-i}$ and Prdx1 $1^{+/}+\mathrm{MEFs}^{-}$were plated as above and treated with increasing amounts of PDGF for $1-10$ min in phenol-free DMEM supplemented with $0.1 \%$ BSA. Following treatment, plates were washed with cold $1 \times$ PBS two times before lysing. Protein lysates were analyzed as above. (h) Quantification of three independent experiments as described under (f) for protein lysates used in (g). Four different sets of Prdx1 WT and KO clones were tested. ${ }^{\prime * \prime}$ indicates statistical significance (Student's $t$-test) of KO and matching WT clone treated with PDGF. $P$-values for phosphorylation of p38MAPK phosphorylation in $\mathrm{H}_{2} \mathrm{O}_{2}$ were $0.003(0.5 \mathrm{~min}), 0.004(1 \mathrm{~min}), 0.04(5 \mathrm{~min}),<0.0001(7 \mathrm{~min})$ and $0.021(10 \mathrm{~min})$. P-values for phosphorylation of ATF-2 were 0.015 (5 min), 0.018 (7 min) and 0.009 (10 min). 

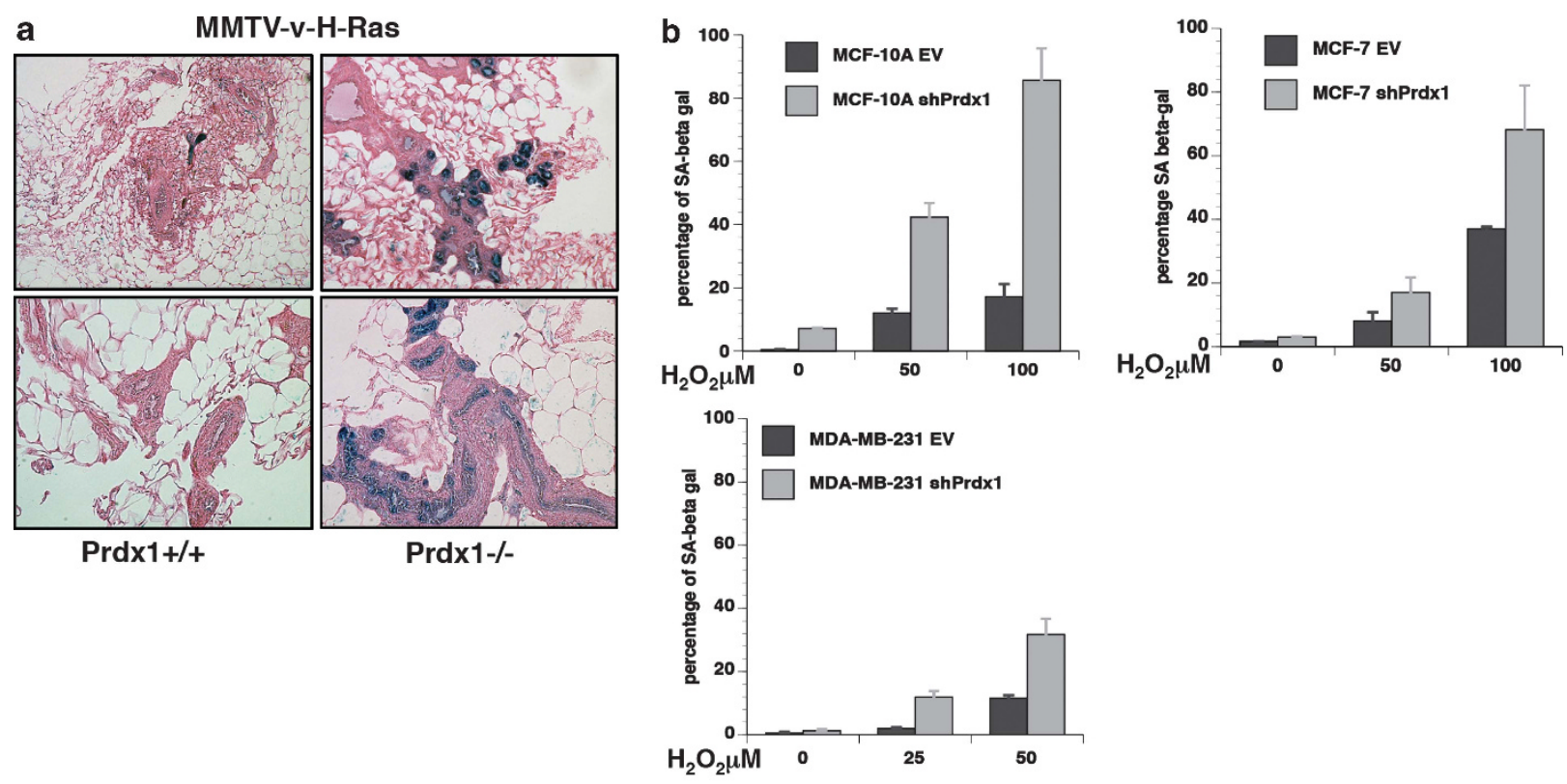

d
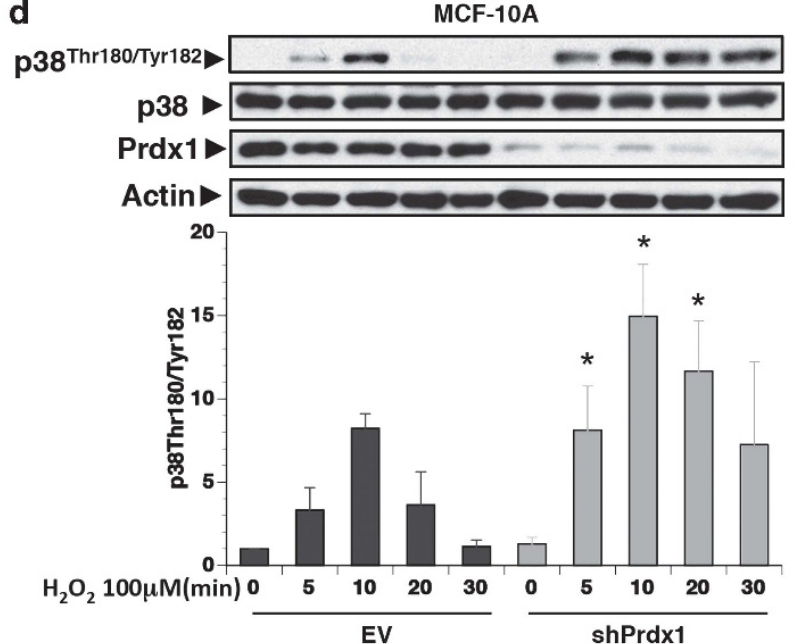

c

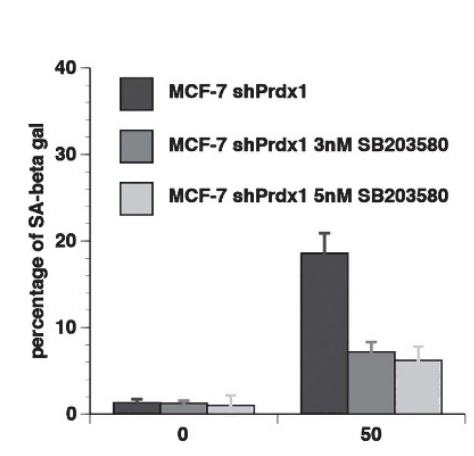

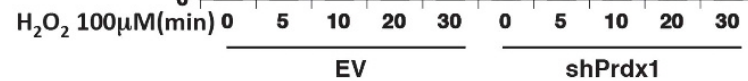

e

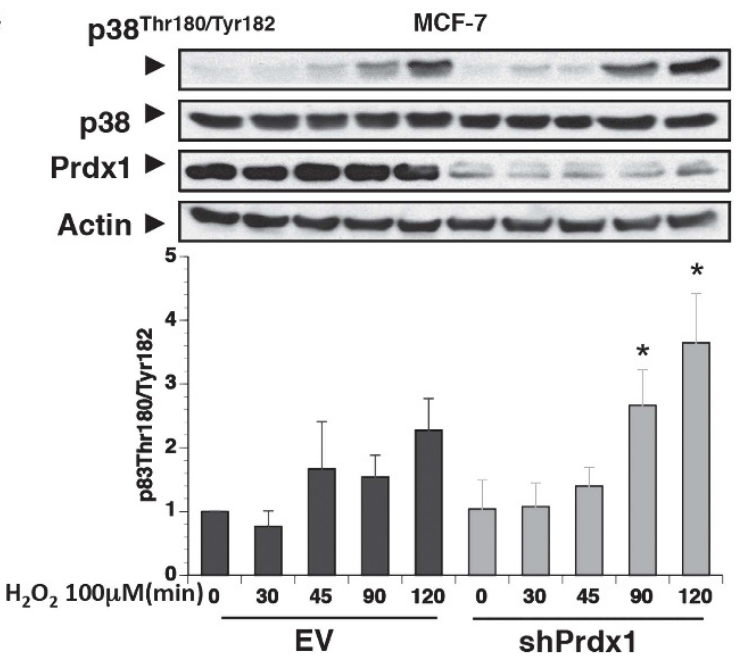

f

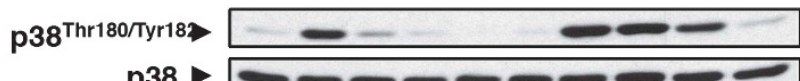

p38 $-\infty-\infty-\infty-\infty$

$\operatorname{Prdx} 1>-\infty-\infty$

Actin

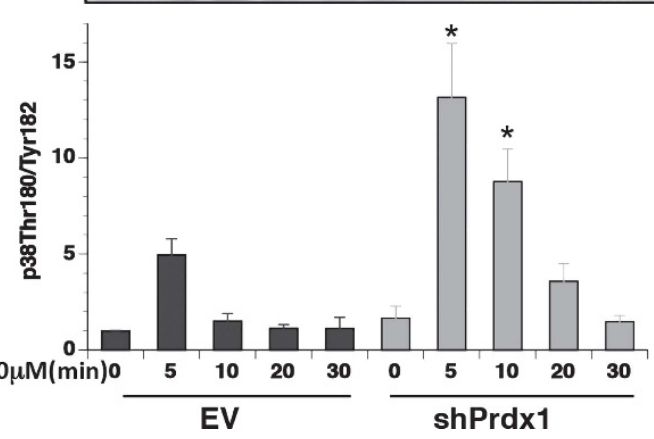


and oncogene-induced senescence,, $92-24$ could inhibit the processes of senescence in $\operatorname{Prdx} 1^{-1-}$ MEFs (Figure 1d). Moreover, PDGF treatment augmented p38MAPK phosphorylation in $\mathrm{H}_{2} \mathrm{O}_{2}$ activity in $\mathrm{Prdx} 1^{-/-}$MEFs, supporting the notion that growth factor signaling stimulates $\mathrm{H}_{2} \mathrm{O}_{2}$ production via NADPH oxidases, ${ }^{1}$ which have recently been implicated to mediate oncogenicinduced senescence. ${ }^{25,26}$

\section{Prdx1 as a sensor for p38MAPK signaling}

Our novel findings suggest Prdx1 acts as an inhibitor of p38MAPK phosphorylation in $\mathrm{H}_{2} \mathrm{O}_{2}$-mediated senescence, since its loss promoted $\mathrm{H}_{2} \mathrm{O}_{2}$-induced senescence in various cell types in vivo and in vitro in a p38MAPK phosphorylation in $\mathrm{H}_{2} \mathrm{O}_{2}$-dependent manner (Figure 2c). Interestingly, the largest increase in SA- $\beta g^{+}{ }^{+}$ cells due to the loss of Prdx1 was seen in the benign MCF-10A cells (Figure $2 \mathrm{~b}$ ). This indicated to us (a) that $\operatorname{Prdx} 1$ 's regulatory role in senescence may be more prominent in non-transformed and (b) that cancer cells may not respond to p38MAPK phosphorylation in $\mathrm{H}_{2} \mathrm{O}_{2}$ signaling the way benign cells do. An uncoupling of p38MAPK phosphorylation in $\mathrm{H}_{2} \mathrm{O}_{2}$ apoptotic signaling under conditions of high cellular ROS was recently suggested. P38MAPK phosphorylation in $\mathrm{H}_{2} \mathrm{O}_{2}$ was found to mediate ROS-dependent pro-apoptotic/anti-oncogenic effects mostly in cells with high p38MAPK phosphorylation in $\mathrm{H}_{2} \mathrm{O}_{2}$ activity and low ROS levels, and not in cancer cells with less p38MAPK phosphorylation in $\mathrm{H}_{2} \mathrm{O}_{2}$ activation, but higher ROS levels. ${ }^{27}$ Considering that cancer cells contain higher levels of ROS compared with normal cells, p38MAPK phosphorylation in $\mathrm{H}_{2} \mathrm{O}_{2}$ signaling may differ in benign compared with malignant cells. Our data suggest that such specific ROS-dependent regulation of cell signaling exists since we describe that the over-oxidation of Prdx1's peroxidatic Cys52 to sulfonic acid differentially modulated

Table 1. Lack of Prdx1 in MMTV-v-H-Ras mice increases SA- $\beta$ gal activity in mammary glandular structures

\begin{tabular}{|c|c|c|c|c|}
\hline SA- $\beta$ gal activity (staining intensity) & $\emptyset$ & + & ++ & +++ \\
\hline MMTV-v-H-Ras $\operatorname{Prdx} 1^{+1+}$ & 3 & 3 & 1 & 0 \\
\hline MMTV-v-H-Ras Prdx $1^{-1-}$ & 0 & 2 & 2 & 3 \\
\hline \multicolumn{5}{|c|}{$\begin{array}{l}\text { Abbreviations: Prdx } 1 \text {, peroxiredoxin } 1 \text {; SA- } \beta \text { gal, senescence-associated } \\
\beta \text {-galactosidase. Mammary glands from MMTV-v-H-Ras Prdx } 1^{+/+} \text {or } \\
\text { Prdx } 1^{-/} \text {were collected and small pieces }(0.5 \times 0.5 \mathrm{~cm}) \text { were processed } \\
\text { for SA- } \beta \text { gal activity. }\end{array}$} \\
\hline
\end{tabular}

MKP-1 and MKP-5. Such a hypothesis excludes the possibility that Prdx1's direct binding to MKP-1 or MKP-5 (Figure 3a) is disulfide based, involving Cys52. Our data support this, given the observation that addition of a reducing agent (TCEP) in the FRETbased fluorescent analysis resulted in comparable $K_{D}$ s: for MKP-5 and MKP-1 (Supplementary Figure 3SA; Table 2). Moreover, although Prdx1 bound to MKP-5 with a higher binding affinity than MKP-1 (Figure 3a), adding equal amounts of unlabeled intact MKP-5 to MKP-5 QSY35-labeled proteins showed dynamic reversibility of protein binding (Supplementary Figure 3SB). The idea that cysteine oxidation regulates signal transduction is not new $^{28}$ however, additional specific examples are needed. We demonstrate that under increasing doses of $\mathrm{H}_{2} \mathrm{O}_{2}$, Prdx1:MKP-1 complexes dramatically decreased and did not contain any detectable over-oxidized Prdx1 (Figure 3c), whereas MKP-5 increasingly associated with over-oxidized Prdx1 (Figure 3d). Moreover, in contrast to Prdx1-WT, Prdx1-Cl binding to MKP-1 was unaffected by $\mathrm{H}_{2} \mathrm{O}_{2}$ (Figure 3e) whereas MKP-5 binding to Prdx1-Cl was comparable to Prdx1-WT (Figure 3f). Although these findings suggest that the process of Cys52 over-oxidation may actively contribute to the dissociation of Prdx 1 from MKP-1, other active cysteines of Prdx1, including Cys83, may prevent dissociation of Prdx1 from MKP-1. Further studies are needed to address this question.

MKP-1 and MKP-5 expression is induced by various ROSinducing stimuli ${ }^{29-34}$ and both are inactivated by ROS due to oxidation of their catalytic cysteines, coinciding with formation of oligomeric structures. ${ }^{13,29,35,36}$ Prdx1 preferentially prevented MKP-5 oxidation-induced oligomerization under conditions where Prdx1:MKP-5 complexes were formed. Moreover, protection of MKP-5 by Prdx1 translated into enhanced phosphatase activity, even under high concentrations of $\mathrm{H}_{2} \mathrm{O}_{2}(100$ and $250 \mu \mathrm{m})$, as p38MAPK phosphorylation in $\mathrm{H}_{2} \mathrm{O}_{2}$ phosphorylation was decreased in the presence of exogenous Prdx1 (Figure 4f). Interestingly, Prdx1-Cl, although bound to MKP-5 under $\mathrm{H}_{2} \mathrm{O}_{2}-$ induced stress, had little influence on preventing MKP-5 oligomerization (Figure 4d) or reversing p38MAPK phosphorylation in $\mathrm{H}_{2} \mathrm{O}_{2}$ dephosphorylation (Figure 4f). In fact, Prdx1-Cl compromised MKP-5 activity toward p38MAPKphosphorylation in $\mathrm{H}_{2} \mathrm{O}_{2}$, which was especially pronounced in samples treated with higher $\mathrm{H}_{2} \mathrm{O}_{2}$ amounts (Figures $4 \mathrm{f}, \mathrm{h}$ and $\mathrm{j}$ ). Considering our binding data, this suggests that over-oxidation of Prdx1-Cys52 preserves MKP-5 activity toward p38MAPKphosphorylation in $\mathrm{H}_{2} \mathrm{O}_{2}$ and prevents its oxidation-induced oligomerization. In contrast to MKP-5, higher concentrations of $\mathrm{H}_{2} \mathrm{O}_{2}(100-250 \mu \mathrm{M})$ decreased Prdx1:MKP-1 complex formation (Figure 3c), leaving Prdx1 unable to protect MKP-1 from oxidation-induced oligomerization, thereby

Figure 2. Prdx1 prevents ROS-induced senescence in breast epithelial cells. (a) Mammary glands from 12- to 14-month-old MMTV-H-RasPrdx $1^{+1+}$ and MMTV-H-Ras-Prdx $1^{-/-}$were stained for SA- $\beta$ gal activity. (b) Prdx1 expression was decreased in various human breast epithelial cells using lentiviral shRNA. MCF-10A, MCF-7 and MDA-MB-231 cells expressing vector control (empty vector $=$ EV) or shPrdx1 were plated at 35000 cells/well in 6-well plates overnight. Cells were treated with $\mathrm{H}_{2} \mathrm{O}_{2}$ in DMEM containing $10 \%$ FBS for 4 days. Following treatment, cells were washed with sterile $1 \times$ PBS and incubated in fresh medium for $24 \mathrm{~h}$, and subcultured at low confluency for 10 days. Plates were stained for SA- $\beta$ gal activity as previously described. ${ }^{53} \mathrm{Up}$ to 6000 cells per treatment and genotype were quantified. (c) MCF-7 cells were plated overnight at 35000 cells/well in 6-well plates, and treated as in (b) with the addition of the p38MAPK phosphorylation in $\mathrm{H}_{2} \mathrm{O}_{2}$ inhibitor SB203580 every 2 days before staining for SA- $\beta$ gal activity. (d-f). MCF-10A, MCF-7 and MDA-MB-231 cells expressing vector control $\left(\right.$ empty vector $=\mathrm{EV}$ ) or shPrdx1 were plated in $6 \mathrm{~cm}$ dishes overnight at $8.0 \times 10^{4}$. The following day, medium was removed and the plates washed in $1 \times$ sterile PBS two times, and incubated in serum-free medium for $120 \mathrm{~min}$. Following equilibration in serum-free medium, cells were treated with $100 \mu \mathrm{M} \mathrm{H} \mathrm{H}_{2} \mathrm{O}_{2}$ for up to $2 \mathrm{~h}$ for MCF-7 cells, and 30 min for MCF-10A and MDA-MB-231 cells. Cells were lysed with $150 \mu \mathrm{l}$ of lysis buffer, and protein lysates were analyzed by western blotting for p38MAPK phosphorylation in $\mathrm{H}_{2} \mathrm{O}_{2}$ phosphorylation, p38MAPK phosphorylation in $\mathrm{H}_{2} \mathrm{O}_{2}$, Prdx1 knock down and actin protein levels. Quantification of three to four independent experiments for each human breast epithelial cell line analyzing phosphorylation of p38MAPK phosphorylation in $\mathrm{H}_{2} \mathrm{O}_{2}$ is placed below each cell line. Density of phosphorylated p38MAPK phosphorylation in $\mathrm{H}_{2} \mathrm{O}_{2}$ western blot bands was analyzed using Image J software (http://rsbweb.nih.gov/ij/) and normalized to densities of p38MAPK phosphorylation in $\mathrm{H}_{2} \mathrm{O}_{2}$ protein bands. Finally, values were normalized to density of untreated EV cells as 1. '*'indicates statistical significance (Student's $t$-test) of shPrdx1 and matching EV clone treated with $\mathrm{H}_{2} \mathrm{O}_{2}$. P-values of p38MAPK phosphorylation in $\mathrm{H}_{2} \mathrm{O}_{2}$ phosphorylation for MCF-10A: 0.049 (5 min), 0.031 (10 min) and 0.019 (20 min); MBA-MD-231: 0.018 (5 min) and 0.013 (10 min); MCF-7: 0.011 (90 min) and 0.028 (120 min). 


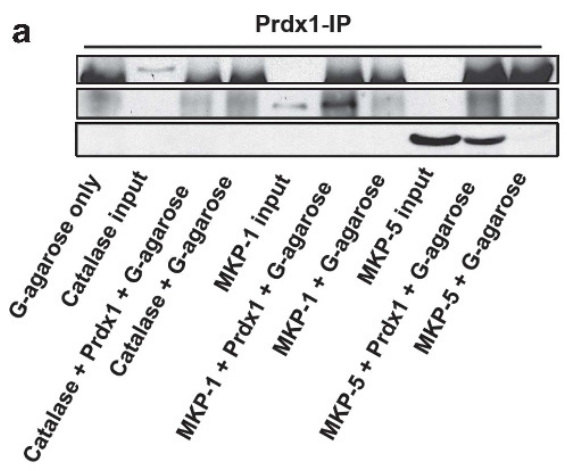

C

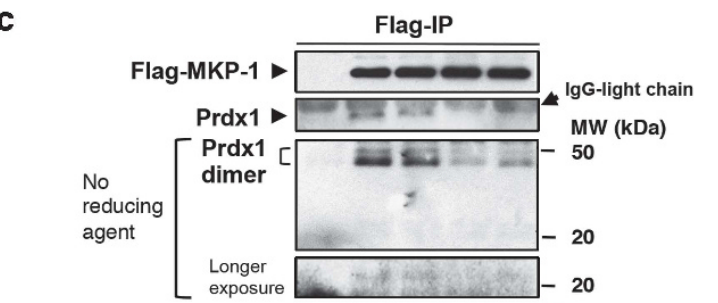

Prdx1 monomer SO2/3 $\square$ /gG-light chain

Flag-MKP-1 * + + + +

$\mathrm{H}_{2} \mathrm{O}_{2} \mu \mathrm{M} \quad 0 \quad 25100250$

d

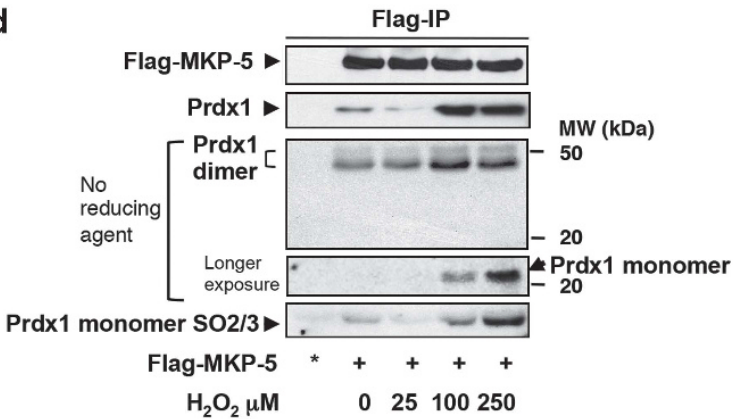

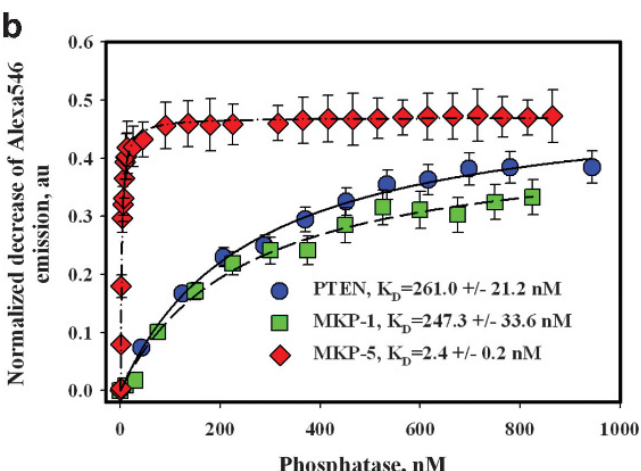

e

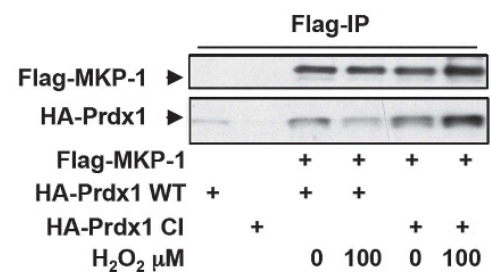

f

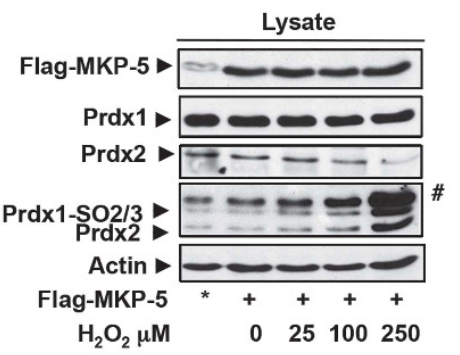

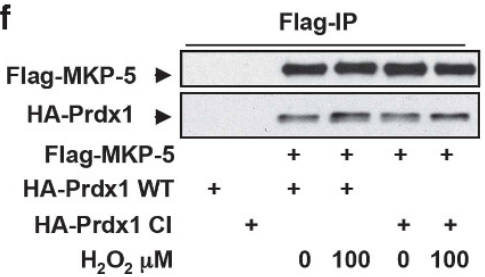

Figure 3. Non-covalent binding of Prdx 1 to MKP-1 and MKP-5 (a) Pull down of recombinant Catalase, MKP-1 and MKP-5 by Prdx 1 conjugated protein $\mathrm{G}$ agarose. The far left lane represents protein agarose $\mathrm{G}$ only to serve as a negative control for non-specific binding. (b) Purified Prdx 1 protein $(2.0 \mathrm{nM}$ ) labeled with Alexa Fluor 546 was titrated with indicated amount of the purified phosphatase proteins labeled with QSY35. Alexa546 fluorescence decrease (normalized to initial Alexa546 emission) was recorded and processed using a 'One Site Saturation model' (Pharmacology application, SigmaPlot 10.0 , SyStat, MA) with best hyperbolic fit $\left(R^{2} \geqslant 0.99\right)$ according to equation: $Y=B_{\max } \times X /\left(K_{\mathrm{D}}+X\right)$ where: $X$ is a concentration of added PTEN (MKP-1 or MKP-5) protein; $Y$ is a normalized decrease in Alexa546 fluorescence corresponding to specific binding of phosphatases; $B_{\max }$ is a saturated number of binding sites with apparent equilibrium dissociation constant $K_{\mathrm{D}}$. Data represent mean \pm s.d. for three independent experiments. The lines represent hyperbolic fit of experimental data for the titration of $2.0 \mathrm{~nm}$ of Alexa546labeled Prx1 with QSY35-labeled: PTEN—solid line $\left(R^{2}=0.99\right)$; MKP-1—dashed line $\left(R^{2}=0.99\right)$; and MKP-5-dotted and dashed line $\left(R^{2}=0.99\right)$. (c, d) 293T HEK cells were transfected with $2.0 \mu \mathrm{g}$ of Flag-MKP-1 and Flag-MKP-5, and treated with increasing amounts of $\mathrm{H}_{2} \mathrm{O}_{2}$ for 30 min in serum-free medium. To assay for binding of endogenous Prdx1, $1000 \mu \mathrm{g}$ of protein lysate was immunoprecipitated using anti-flag affinity matrix and incubated $3 \mathrm{~h}$ at $4{ }^{\circ} \mathrm{C}$ in an hypoxic chamber. The affinity matrix was harvested by centrifugation at $3000 \mathrm{~g}$ for $2 \mathrm{~min}$, and washed with $0.5 \mathrm{ml}$ of lysis buffer three times. The resin was resuspended in $20 \mu \mathrm{l}$ of reducing or non-reducing SDS-PAGE sample buffer, boiled $10 \mathrm{~min}$, and analyzed by western blotting for MKP expression, Prdx1 and Prdx1Cys52SO3 binding. *IP from untransfected cells. Co-IPs were also analyzed in the absence of $\beta$-mercaptoethanol. No Prdx1 dimer staining positive for SO2/3 was detected. "Detection of a higher molecular weight 2-Cys Prdx family member. Co-IP unbound fraction can be found in Supplementary Figure S3B. (e, f) 293T HEK cells were cotransfected with Flag-MKP-1 or Flag-MKP-5 either with HA-Prdx1WT or with $\mathrm{HA}-\mathrm{Prdx} 1 \mathrm{Cl}$, and treated with increasing amounts of $\mathrm{H}_{2} \mathrm{O}_{2}$ for $30 \mathrm{~min}$ in serum-free medium. For co-IP, $1000 \mu \mathrm{g}$ of lysate was added to anti-flag affinity matrix and incubated for $1 \mathrm{~h}$ at $4{ }^{\circ} \mathrm{C}$. Following incubation, the affinity matrix was harvested as stated above, resuspended in $20 \mu$ l of reducing sample buffer, and boiled for 10 min. Binding of HA-Prdx1WT and HA-Prdx1Cl was determined by western blotting. Analysis of cell lysate for protein expression can be found in Supplementary Figure S3C. 
Table 2. Non-covalent binding of Prdx1 with MKP-5, MKP-1 and PTEN

\begin{tabular}{lcc}
\hline $\mathrm{K}_{D}$ & - TCEP & + TCEP \\
\hline MKP-5 & $2.5 \pm 0.4 \mathrm{nM}$ & $3.1 \pm 0.5 \mathrm{nM}$ \\
MKP-1 & $210 \pm 19.5 \mathrm{nM}$ & $215.0 \pm 21.5 \mathrm{nM}$ \\
PTEN & $215.0 \pm 19.5 \mathrm{nM}$ & $219.5 \pm 22.5 \mathrm{nM}$ \\
\hline
\end{tabular}

Abbreviations: KD, knockdown; MKP, MAP kinase phosphatase; Prdx1, peroxiredoxin 1 ; SA- $\beta$ gal, senescence-associated $\beta$-galactosidase galactosidase; TCEP, tris-(2-carboxyethyl)-phosphine. To address if covalent binding exists between Prdx1 and MKP-1 or MKP-5, the reducing agent TCEP was added to the FRET-based fluorescent analysis shown in Supplementary Figure 3SA. This resulted in comparable $K_{\mathrm{D}} \mathrm{S}$ for MKP-5 and MKP-1.

blunting MKP-1 activity toward p38MAPK phosphorylation in $\mathrm{H}_{2} \mathrm{O}_{2}$. Actually, under conditions of lower $\mathrm{H}_{2} \mathrm{O}_{2}$ concentrations $(25-100 \mu \mathrm{M})$, we found that Prdx1 WT increased MKP-1 oligomerization, whereas $\operatorname{Prdx} 1-\mathrm{Cl}$, which still binds to MKP-1 under $\mathrm{H}_{2} \mathrm{O}_{2}$-induced stress, appeared to protect MKP-1 from oligomer formation (Figure 4c). Interestingly, this translated into less dephosphorylation of p38MAPK phosphorylation in $\mathrm{H}_{2} \mathrm{O}_{2}$ when MKP-1 was co-expressed with Prdx1 WT compared with coexpression with Prdx1-Cl (Figures $4 \mathrm{e}, \mathrm{g}$ and i). Supporting this, MKP-1 phosphatase activity toward DiFMUP was decreased only in the presence of Prdx1 after $\mathrm{H}_{2} \mathrm{O}_{2}$ treatment (Figure 5b), although several studies have described that MKP-1 is readily over-oxidized and inactivated by ROS. ${ }^{29,37}$ This suggests that (a) under non- $\mathrm{H}_{2} \mathrm{O}_{2}$ conditions Prdx1 promotes MKP-1 activity, whereas under $\mathrm{H}_{2} \mathrm{O}_{2}-$ induced stress Prdx1 inactivates MKP-1 and (b) it is unlikely that $\mathrm{Prdx} 1$ competes with p38MAPK phosphorylation in $\mathrm{H}_{2} \mathrm{O}_{2}$ for MKP-1 binding. ${ }^{38-40}$ Little is known about how MKP-5 reacts to oxidative stress. Our data suggest that recombinant MKP-5 phosphatase activity is decreased by $\mathrm{H}_{2} \mathrm{O}_{2}$ in a dose-dependent manner, and the presence of $\operatorname{Prdx} 1$ protected and even slightly enhanced MKP-5 activity.

Taken together, we describe that over-oxidation of $\operatorname{Prdx} 1$ 's peroxidatic cysteine adjusts MKP-1 and MKP-5 activity in an $\mathrm{H}_{2} \mathrm{O}_{2}-$ dependent manner, thereby regulating P38MAPK phosphorylation in $\mathrm{H}_{2} \mathrm{O}_{2}$ activity. Given the diversity of p38MAPK phosphorylation in $\mathrm{H}_{2} \mathrm{O}_{2}$ signaling, such regulation may be meaningful for redoxstress signaling. In this context, our data may support recent findings published by the Veal laboratory, where in an elegant study the over-oxidation of yeast Prdx Tpx 1 was found critical for Trx-mediated repair of oxidized proteins. In essence, this study proposed that in an environment of elevated oxidative stress, where Prdx Tpx1 is found over-oxidized and therefore 'nonreducible' by Trx, cell survival is promoted through protein repair by the available Trx. ${ }^{41}$ Given our data, we suspect that MKP-5 is perhaps a Trx substrate. This needs to be examined in the future.

A specific role for Prdx1 as a promoter of MKP-5 activity in p38MAPK signaling in breast cancer senescence

To date, no role for MKP-1 or MKP-5 in breast cancer or senescence has been established. MKP-5 has been implicated in prostate cancer, as a Vitamin D-inducible gene, which indirectly inhibits secretion of pro-carcinogenic inflammatory factors including IL-6, a key player in senescence-associated secretory phenotype, ${ }^{42}$ through blocking p38MAPK phosphorylation in $\mathrm{H}_{2} \mathrm{O}_{2}$ signaling. ${ }^{43}$ Our data support this, since MKP-5 ${ }^{\mathrm{WT}}$ was a potent inhibitor of $\mathrm{H}_{2} \mathrm{O}_{2}$-induced senescence in MCF-7 cells, whereas MKP-5 ${ }^{\mathrm{Cl}}$ was not (Figure 6a). MCF-7 cells expressing MKP$1^{\mathrm{WT}}$ or MKP-1 ${ }^{\mathrm{Cl}}$ showed equal suppression of senescence, but no differences in the amount of p38MAPK phosphorylation in $\mathrm{H}_{2} \mathrm{O}_{2}$ phosphorylation, suggesting that Prdx1 regulates MKP-1 activity toward p38MAPK phosphorylation in $\mathrm{H}_{2} \mathrm{O}_{2}$ (Figure 6b). Whether MKP-1-Cl can bind to p38MAPK phosphorylation in $\mathrm{H}_{2} \mathrm{O}_{2}$ needs to be determined. Recent work demonstrated that MKP-1 overexpression in MCF-7 cells prevents $\mathrm{H}_{2} \mathrm{O}_{2}$-induced cell death. Since MCF-7 cells express endogenous Prdx1, this difference is perhaps due to the high dose of $\mathrm{H}_{2} \mathrm{O}_{2}(300 \mu \mathrm{m})$ given, whereas Prdx1 is most likely over-oxidized and less available to bind to MKP-1, thereby freeing MKP-1 to dephosphorylate p38 and JNK. ${ }^{44}$

MKP-1 and MKP-5 specificity is toward p38MAPKphosphorylation in $\mathrm{H}_{2} \mathrm{O}_{2} / \beta$, and not p38MAPK $\delta / \gamma .{ }^{45}$ Interestingly, treating MCF7 cells with $25 \mu \mathrm{M} \mathrm{H}_{2} \mathrm{O}_{2}$ revealed a slower migrating band only in cells expressing $\mathrm{MKP}-5^{\mathrm{WT}}$ and to a lesser extent $\mathrm{MKP}-5^{\mathrm{Cl}}$ (Figure 6b). This band was detected with anti-p38MAPK $\delta$, not anti-p38MAPK phosphorylation in $\mathrm{H}_{2} \mathrm{O}_{2}$ antibody, suggesting a novel role for p38MAPK $\delta$ in senescence. This idea fits, given that p38MAPK $\delta$ activity seemingly promotes oncogenesis, ${ }^{46}$ and MCF-7-MKP-5 ${ }^{\text {WT }}$ formed $\sim 2.5$-fold more colonies in soft agar compared with MCF-7-MKP-5 $5^{\mathrm{Cl}}$ cells (Figure 6c). Therefore, perhaps suppression of p38MAPK phosphorylation in $\mathrm{H}_{2} \mathrm{O}_{2}$ represses senescence and promotes oncogenesis by p38MAPK $\delta$ activation. Expression of MKP-1 ${ }^{\mathrm{WT}}$ also led to a reduction in colony numbers, compared with MCF-7-MKP-1 ${ }^{\mathrm{Cl}}$ cells. This may be because JNK is essential for MCF-7 proliferation, since knockdown of JNK in MCF-7 cells inhibited MCF-7 proliferation; ${ }^{47}$ over-expression of MKP-1, often referred to as the 'JNK phosphatase, ${ }^{48}$ may have a similar effect.

In summary, our data suggest that under normal ROS homeostasis, Prdx1 promotes MKP-1 and MKP-5 activity (Figure 7). Under increasing ROS levels, Prdx1 becomes over-oxidized on its peroxidatic cysteine Cys52, Prdx1-Cys52-SO3 forms less Prdx1/ MKP-1 complexes leading to MKP-1 inactivation and p38MAPK phosphorylation in $\mathrm{H}_{2} \mathrm{O}_{2}$ activation. Conversely, Prdx1-Cys52-SO3 binds to MKP-5 and preserves MKP-5 activity, ensuring P38MAPK phosphorylation in $\mathrm{H}_{2} \mathrm{O}_{2}$ inhibition. We speculate that activation of MKP-5-insensitive p38MAPK isoforms or JNK signaling may become activated and induce cancer-associated senescence. Clearly, further studies are needed to address this. Collectively, our findings provide compelling novel evidence that the peroxidatic cysteine Cys52 of Prdx1 serves as a sensor in ROS signaling, expanding the function of $\operatorname{Prdx} 1$ beyond its peroxidase activity.

\section{MATERIALS AND METHODS}

Reagents and cell culture

All chemicals, including 5-Bromo-4-chloro-3-indolyl $\beta$-D-galactopyranoside, Flag-agarose conjugated beads and recombinant $\operatorname{Prdx} 1$ protein, were purchased from Sigma-Aldrich (St Louis, MO, USA) unless otherwise noted. Antibodies against pan p38, p-p38 (Thr180/Tyr182), p-ATF2 (Thr69/71), MKP-5, HA tag and Flag tag were purchased from Cell Signaling (Boston, MA, USA). Actin was purchased from Chemicon (EMD Millipore Corporation, Billerica, MA, USA), antibodies recognizing $\operatorname{Prdx} 1$ and $\operatorname{Prdx} 1-\mathrm{SO}_{3}$ were purchased from Abcam (Cambridge, MA, USA), and MKP-1 from Santa Cruz (Santa Cruz, CA, USA). Recombinant MKP-1 and MKP-5 proteins were purchased from Enzo Life Sciences (Farmingdale, NY, USA). Materials for cell culture medium including DMEM, FBS, Glutamax, NEAA, sodium pyruvate, Pen/Strep, insulin, DMEM without Phenol Red, PBS and PDGF were purchased from Invitrogen (Grand Island, NY, USA). MEFs were generated from Prdx $1^{+/-}$mice as described, ${ }^{7}$ MCF-10A, MDA-MB-231 and MCF-7 cells were maintained as described. ${ }^{49,50}$

\section{Constructs}

Expression vectors used for 293T/17 (ATCC) transfections included: Flagp38MAPK phosphorylation in $\mathrm{H}_{2} \mathrm{O}_{2}$ in pcDNA3.1, HA-Prdx1 (WT and mutant) in PCGN, Flag-MKP1/5 in PQCXIP (WT and mutant), and Myc-WTMKP-5 in pSR phosphorylation in $\mathrm{H}_{2} \mathrm{O}_{2}$ expression vector. The MKP-5 mutant was constructed by PCR-based mutagenesis (Stratagene, La Jolla, CA, USA). Flag-MKP-1/5 (both WT and mutants) were cloned into Agel/ BamHI of pQCXIP, and used for both 293T experiments, as well as making retrovirus for infection of MCF-7 cells. The expression plasmid pLKO.1 was used for shPrdx 1 . 
a

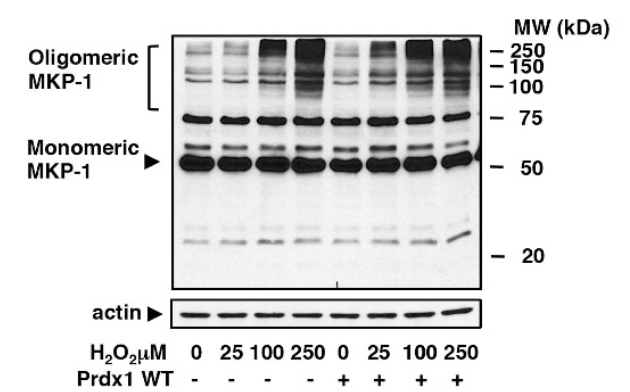

C

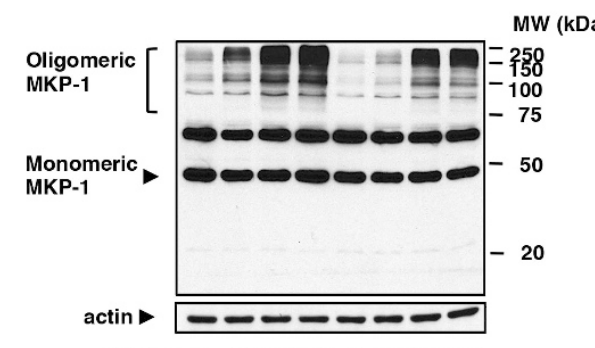

$\mathrm{H}_{2} \mathrm{O}_{2} \mu \mathrm{M} \quad 0 \quad 25100250025100250$ Prdx1 Cl - - - - + + +

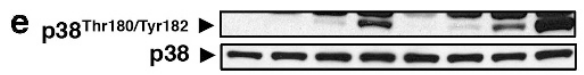

p38 $-\infty-\infty-\infty$

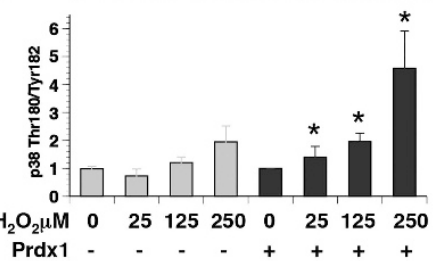

g

$g_{\mathrm{p} 3}$

h b

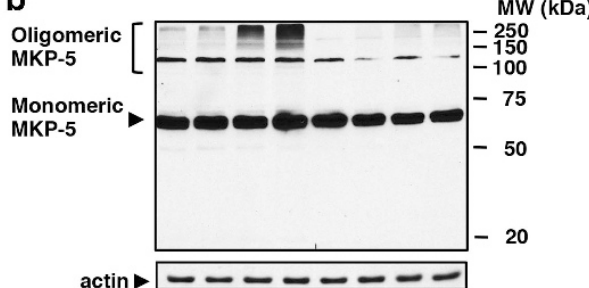

$\mathrm{H}_{2} \mathrm{O}_{2} \mu \mathrm{M} \quad 0 \quad 25100250025100250$

Prdx1 WT - - - - + + + +

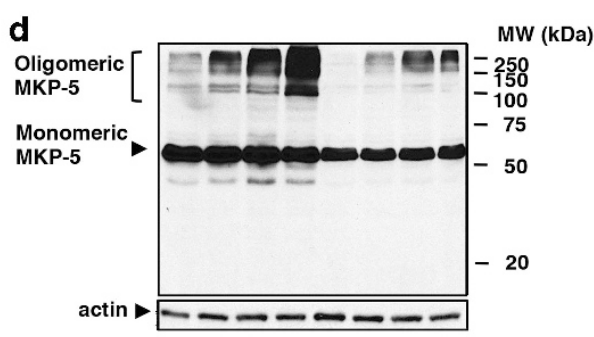

$\mathrm{H}_{2} \mathrm{O}_{2} \mu \mathrm{M} 025100250025100250$

Prdx1 Cl - - - + + + +

f p38 $^{\text {Thr180/Tyr182 }} \square \cdots$

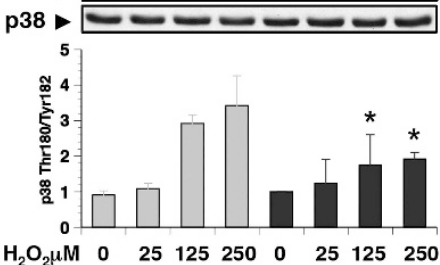

$\mathrm{H}_{2} \mathrm{O}_{2} \mu \mathrm{M} \quad 0 \quad 25125250 \quad 0 \quad 25125250$

Prdx1 - - - - + + + +

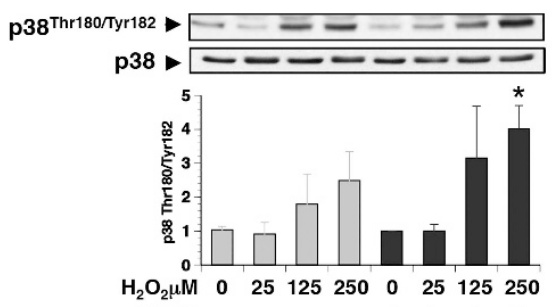

Prdx1 - - ++++

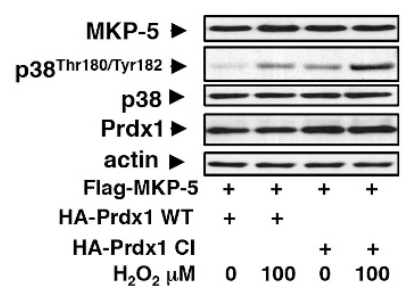

Figure 4. Prdx1 protects MKP-5 from oxidation-induced oligomerization and inactivation. (a, b) Flag-MKP-1 or Myc-MKP-5 was over-expressed together with untagged Prdx1 in 293T cells, using $1.0 \mu \mathrm{g}$ of DNA. (Note: initial experiments included N-terminal tagged Prdx 1 proteins. This enhanced slightly the MKP-1 oligomerization; we therefore used untagged Prdx1.) Cells were treated for 30 min with increasing concentrations of $\mathrm{H}_{2} \mathrm{O}_{2}$ in serum-free medium, and protein lysates analyzed under non-reducing conditions by western blotting for oligomerization of MKP-1 and MKP-5 $(n=3)$. (c, d) As in $(\mathbf{a}, \mathbf{b})$, with the exception of co-expressing untagged Prdx1-CI. ( $(n=3)(\mathbf{e}-\mathbf{h})$ Western blot analysis of (a-d) for phosphorylation of p38MAPK phosphorylation in $\mathrm{H}_{2} \mathrm{O}_{2}$. Quantification includes three independent experiments. Density of phosphorylated p38MAPK phosphorylation in $\mathrm{H}_{2} \mathrm{O}_{2}$ western blot bands was analyzed using Image J software (http:// rsbweb.nih.gov/ij/) and normalized to densities of p38MAPK phosphorylation in $\mathrm{H}_{2} \mathrm{O}_{2}$ protein bands. Finally, values were normalized to density of untreated cells expressing exogenous Prdx1. P-values of p38MAPK phosphorylation in $\mathrm{H}_{2} \mathrm{O}_{2}$ phosphorylation for MKP-1 + WTPrdx1: $0.011\left(25 \mu \mathrm{M} \mathrm{H}_{2} \mathrm{O}_{2}\right), 0.002\left(100 \mu \mathrm{M} \mathrm{H}_{2} \mathrm{O}_{2}\right)$ and $0.004\left(250 \mu \mathrm{M} \mathrm{H}_{2} \mathrm{O}_{2}\right)$. MKP-1 + CI-Prdx1: $0.01\left(100 \mu \mathrm{M} \mathrm{H} \mathrm{O}_{2}\right)$. MKP-5 + WT-Prdx1: $0.04(100 \mu \mathrm{M}$ $\left.\mathrm{H}_{2} \mathrm{O}_{2}\right), 0.013\left(250 \mu \mathrm{M} \mathrm{H}_{2} \mathrm{O}_{2}\right)$. MKP-5 + Cl-Prdx1: $0.014\left(250 \mu \mathrm{M} \mathrm{H} \mathrm{H}_{2} \mathrm{O}_{2}\right)$. Western blots showing MKP-1 or MKP-5 co-expressed with Prdx1 WT or Prdx1-Cl run under non-reducing conditions can be found in Supplementary information along with western blot analysis under reducing conditions (Supplementary Figures 4SA and B). (i, j) 293T HEK cells were co-transfected with Flag-MKP-1 or Flag-MKP5 and with Prdx1 WT or Prdx1 Cl, respectively, and treated with increasing amounts of $\mathrm{H}_{2} \mathrm{O}_{2}$ for 30 min in serum-free medium. Lysates were run under reducing conditions, and analyzed by western blotting for phosphorylation of p38MAPK phosphorylation in $\mathrm{H}_{2} \mathrm{O}_{2}$ on Thr180 and Tyr182, expression of p38MAPK phosphorylation in $\mathrm{H}_{2} \mathrm{O}_{2}$, MKPs and Prdx1. 


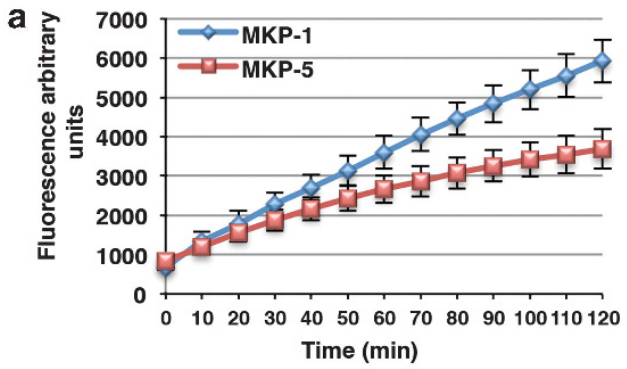

b

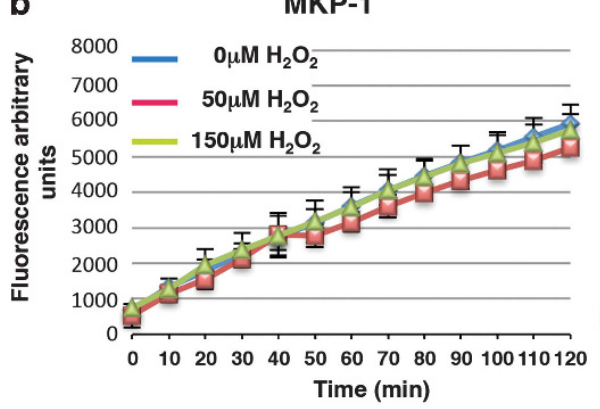

C

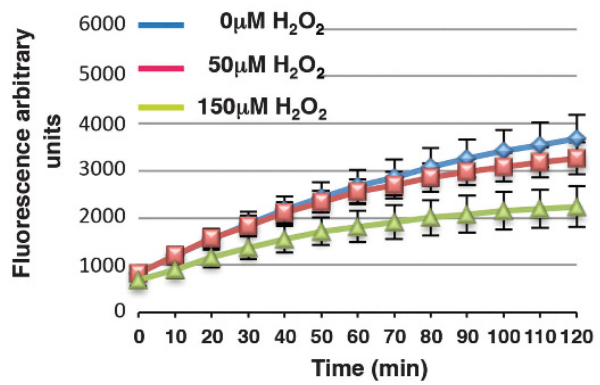

MKP-1:Prdx1

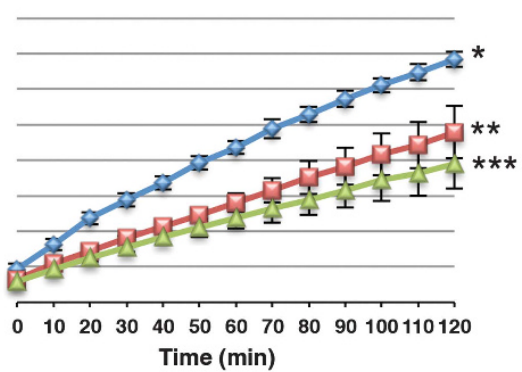

MKP-5:Prdx1

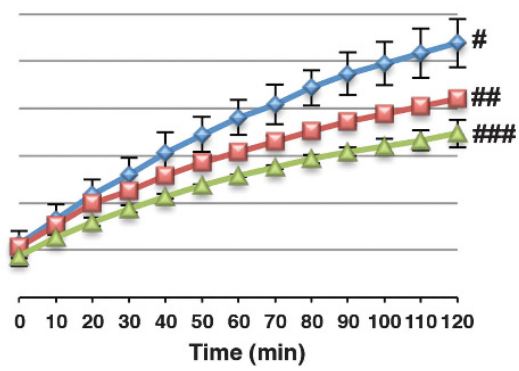

Figure 5. Prdx 1 promotes MKP-5 catalytic activity and protects it from $\mathrm{H}_{2} \mathrm{O}_{2}$-induced stress. Time courses of $160 \mu \mathrm{m}$ DiFMUP hydrolysis by recombinant MKP-1 and MKP-5 phosphatase activity were measured in the presence of Prdx1 and $\mathrm{H}_{2} \mathrm{O}_{2}$. An equimolar ratio of MKP:Prdx1 recombinant protein was added to $1 \times$ reaction buffer in $1.5 \mathrm{ml}$ eppendorf tubes at room temperature. Concentrations of MKPs were kept the same in each reaction. $\mathrm{H}_{2} \mathrm{O}_{2}$ was diluted in sterile $\mathrm{H}_{2} \mathrm{O}$, and added to the recombinant proteins and allowed to incubate at room temperature for $10 \mathrm{~min}$. The proteins were pipetted into a black, clear bottom 96-well plate, followed by the addition of $160 \mu \mathrm{m}$ of DiFMUP substrate. The plate was covered in foil, and read at $\sim 360 / 460 \mathrm{~nm}$ on a fluorescence plate reader every 10 min for $2 \mathrm{~h}$. X axis represents time in minutes, $\mathrm{y}$ axis represents fluorescent signal generated DiFMUP hydrolysis. (a) Comparison of MKP-1 and MKP-5 catalytic activity. (b) Left panel: MKP-1 activity over time in the presence of increasing concentrations of $\mathrm{H}_{2} \mathrm{O}_{2}$. Right panel: same as in left panel, in the presence of Prdx1. (c) Left panel: MKP-5 activity over time in the presence of increasing concentrations of $\mathrm{H}_{2} \mathrm{O}_{2}$. Right panel: same as left panel, in the presence of Prdx1. Statistical analysis: Utilization of substrate was measured for MKP-1 and MKP-5 at three levels of $\mathrm{H}_{2} \mathrm{O}_{2}$ concentration $(0,0.05$ and 0.15 mM) in the absence or presence of Prdx1. Prdx1 treatment effects over time on MKP activity were modeled in a random effects model, allowing for fixed effects of Prdx1, time in minutes. Random intercepts and experimental effects were included. The six tests of differences in treatment effects (MKP activity without Prdx1 compared with MKP activity in the presence of Prdx1) over time were all statistically significant at the

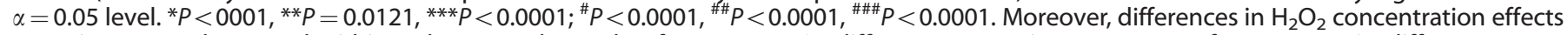
over time were also tested within Prdx1-treated samples: for MKP1, $\mathrm{H}_{2} \mathrm{O}_{2}$ differences over time: $P<0.0001 ;$ for $\mathrm{MKP}, \mathrm{H}_{2} \mathrm{O}_{2}$ differences over time: $P=0.0002$.

\section{MEF oxidative stress experiments}

Prdx $1^{-1-}$ and Prdx $1^{+/+}$MEFs were serum starved in $0.25 \%$ FBS for $48 \mathrm{~h}$ before treatment. Cells were either treated with PDGF in phenol-free DMEM supplemented with $0.1 \%$ BSA or with increasing doses $(25-200 \mu \mathrm{M})$ of $\mathrm{H}_{2} \mathrm{O}_{2}$ in serum-free DMEM for $10 \mathrm{~min}$. Cell lysate was processed as previously described. ${ }^{7}$

\section{Co-immunoprecipitation studies}

293T/17 (ATCC) cells were transfected with various constructs as described.7 For co-immunoprecipitation, $750-1000 \mu \mathrm{g}$ of protein was subjected to immunoprecipitation using Anti-FLAG M2 affinity gel. Affinity matrix was harvested by centrifugation at $3000 \mathrm{~g}$ for $2 \mathrm{~min}$ and washed three times. The resin was resuspended in reducing SDS-PAGE loading buffer, boiled $10 \mathrm{~min}$, and analyzed by SDS-PAGE/western blotting.

\section{Prdx1:MKP pulldown}

MKP-1/5 recombinant proteins were incubated with equimolar concentrations $(100 \mathrm{nM})$ of $\mathrm{Prdx} 1$ overnight at $4{ }^{\circ} \mathrm{C}$ in buffer containing $20 \mathrm{~mm}$ Hepes (pH 8.0), $150 \mathrm{~mm} \mathrm{NaCl}, 2 \mathrm{~mm} \mathrm{MgCl}, 1 \mathrm{~mm}$ DTT, $50 \mu \mathrm{m}$ PMSF, $5 \mathrm{~mm}$ benzamidine hydrochloride, $3 \mu \mathrm{m}$ aprotinin and $1 \%$ Triton X-100. Recombinant proteins were added to $50 \mu \mathrm{l}$ of $\operatorname{Prdx} 1$-conjugated Protein $\mathrm{G}$ agarose matrix, and allowed to incubate at $4{ }^{\circ} \mathrm{C}$ for $1 \mathrm{~h}$. The resin was then harvested and washed as above. Proteins were eluted with reducing SDSloading buffer, boiled for $10 \mathrm{~min}$, and analyzed by SDS-PAGE/western blotting.

\section{Fluorescent Kd analysis}

$\operatorname{Prdx} 1$ protein was incubated with succinimidyl ester of Alexa Fluor 546 carboxylic acid (Invitrogen) and purified MKP proteins were incubated with succinimidyl ester of QSY35 acetic acid (Invitrogen, both at $5 \times$ excess to 


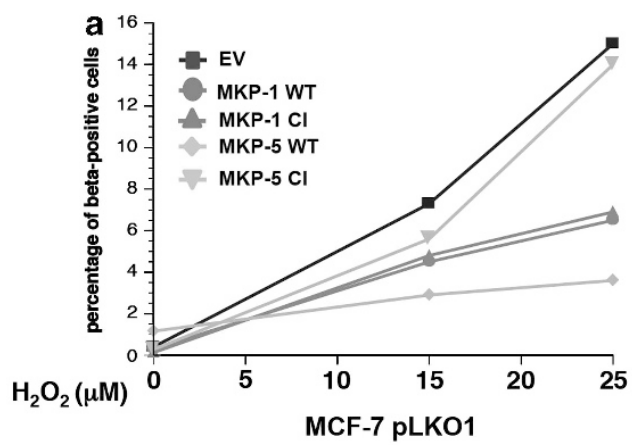

b

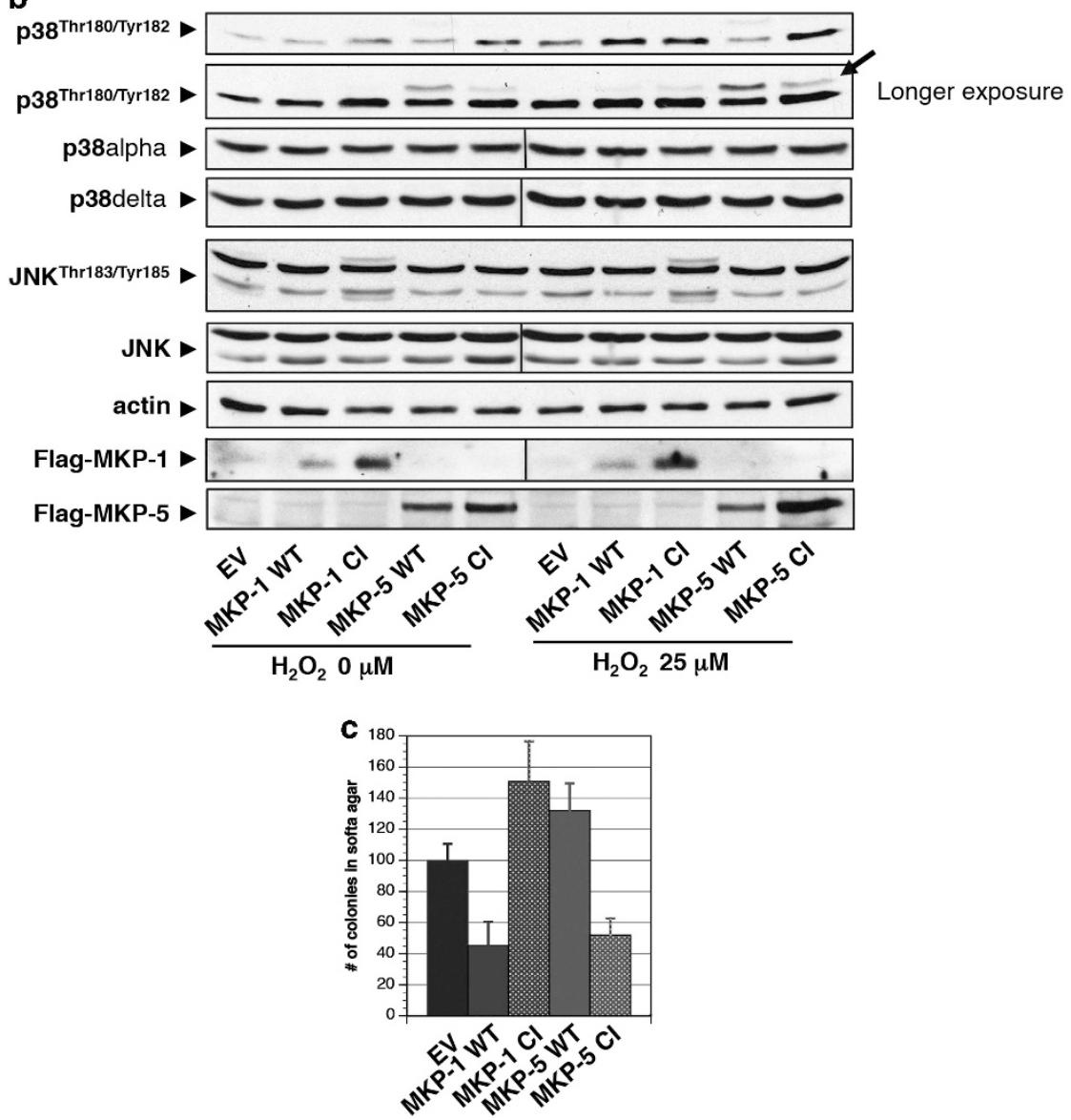

Figure 6. Prdx1 prevents ROS-induced senescence in MCF-7 cells by promoting MKP-5 activity. (a, b) MCF-7 cells were infected with retrovirus for Flag-tagged MKP-1 WT, MKP-1 C258S, MKP-5 WT or MKP-5 C408S and 7 days later with lentivirus for shPrdx1 or EV. After 5 days of selection, cells were plated overnight at 35000 cells/well in 6-well plates and treated with $\mathrm{H}_{2} \mathrm{O}_{2}$ every day for 4 days in DMEM containing $10 \%$ FBS Following treatment, cells were allowed to recover for 10 days in fresh medium, and stained for SA- $\beta$ gal activity as previously stated. Blue cells were quantified as described in Figure 2. Plot is a representative of two independent experiments. MCF-7 cells expressing MKP-1 and MKP-5 WT and $\mathrm{Cl}$ mutants were plated in $6 \mathrm{~cm}$ dishes overnight at $8.0 \times 10^{4}$, and then treated with $5 \mu \mathrm{m}$ of MG132 proteasome inhibitor overnight. The following day, medium was removed and the plates washed in $1 \times$ sterile PBS two times, and incubated in serum-free medium for 120 min. Following equilibration in serum-free medium, cells were treated with $25 \mu \mathrm{M} \mathrm{H}_{2} \mathrm{O}_{2}$ treatment for $2 \mathrm{~h}$. Cells were lysed with 150 by the addition of $160 \mu \mathrm{l}$ of lysis buffer, and protein lysates were analyzed by western blotting for p38MAPK phosphorylation in $\mathrm{H}_{2} \mathrm{O}_{2}$ phosphorylation on Thr180/Tyr182, JNK phosphorylation on Thr183/Tyr185, p38MAPK $\delta$ levels and actin protein levels. Arrow indicates slower migrating band, which could be phosphorylated p38MAPK $\delta$. (c) Cells from (a) were plated in soft agar, and colonies were counted.

protein) at RT overnight under constant agitation to label primary amines according to manufacturer recommendations. The reaction mixtures were processed using BioSpin 6 (Bio-Rad, Hercules, CA, USA) size-exclusion spin column to remove unreacted dyes and exchange reaction buffers to PBS $(\mathrm{pH}=7.4)$. The resultant labeled protein concentration was analyzed with standard Bradford assay (Bio-Rad). The analysis is based on quenching of Alexa546 fluorescence by QSY35 (the distance of $50 \%$ quenching is $\sim 25 \AA$ ), and was performed as previously described. ${ }^{17}$ The $\mathrm{Kd}$ is a concentration of $50 \%$ Alexa546 emission decrease.

Recombinant MKP-1 and MKP-5 phosphatase assay

Recombinant MKP-1 and MKP-5 phosphatase activity was analyzed in the presence and absence of Prdx1 under increasing $\mathrm{H}_{2} \mathrm{O}_{2}$ stress using 


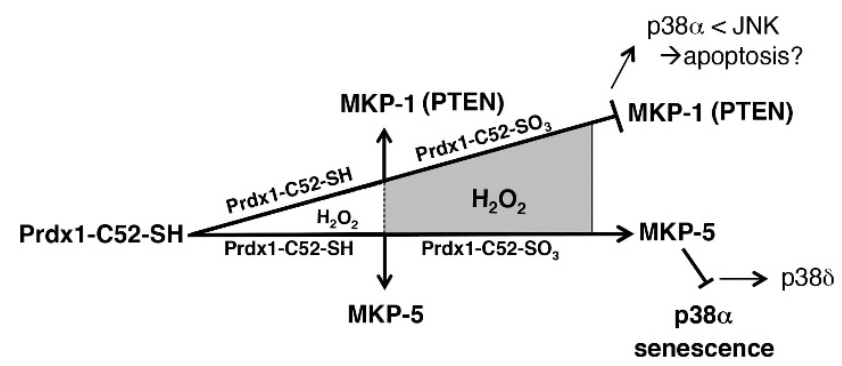

Figure 7. The peroxidatic cysteine Cys52 of $\operatorname{Prdx} 1$ is a sensor in ROS signaling. Under normal ROS homeostasis, $\operatorname{Prdx} 1$ promotes both MKP-1 and MKP-5 activity. However, under increased ROS, Prdx1Cys52-SO3 forms less Prdx1/MKP-1 complexes leading to MKP-1 inactivation. This is comparable to data we obtained for PTEN. ${ }^{7}$ Conversely, in the presence of MKP-5, Prdx1-Cys52-SO3 binds to MKP-5 and preserves MKP-5 activity. We therefore speculate that MKP-1, which in some instances prefers JNK over p38MAPK phosphorylation in $\mathrm{H}_{2} \mathrm{O}_{2}$ as a substrate ${ }^{52}$, is inactivated under high oxidative stress (because of the dissociation from Prdx1) to allow JNK activity. MKP-5 on the other hand favors, depending on the cellular context, p38MAPK phosphorylation in $\mathrm{H}_{2} \mathrm{O}_{2}$ over JNK as a substrate. ${ }^{53}$ This way, MKP-5 activation by $\operatorname{Prdx} 1$ is thereby preventing p38MAPK phosphorylation in $\mathrm{H}_{2} \mathrm{O}_{2}$ signaling in $\mathrm{H}_{2} \mathrm{O}_{2}-$ induced senescence. The net outcome of all this may be that Prdx1 in an $\mathrm{H}_{2} \mathrm{O}_{2}$ dose-dependent manner prevents oxidative p38MAPK phosphorylation in $\mathrm{H}_{2} \mathrm{O}_{2}$-mediated stress-induced senescence to promote JNK-mediated signaling.

the EnzChek Phosphatase Assay Kit from Molecular Probes (Life Technologies, Grand Island, NY, USA). Various concentrations $(80-320 \mu \mathrm{m})$ of the substrate DiFMUP were used to assess the activity of MKP-1 and MKP-5 (30 pmols each in $200 \mu \mathrm{l}$ reaction buffer) over $2 \mathrm{~h}$, before deciding on $160 \mu \mathrm{m}$ DiFMUP for all experiments. Using a 1:1 molar ratio of MKP:Prdx1, proteins were pipetted into a black, clear-bottom 96-well plate (Costar) following addition of $\mathrm{H}_{2} \mathrm{O}_{2}$, and hydrolysis of DiFMUP was measured at $\sim 360 / 460 \mathrm{~nm}$ using a fluorescence plate reader.

\section{$\mathrm{H}_{2} \mathrm{O}_{2}$-induced stress and senescence in MCF-10A, MCF-7 and MDA-MB-231 cells}

For detection of p38MAPK phosphorylation in $\mathrm{H}_{2} \mathrm{O}_{2}$ phosphorylation, cells were plated at $8.0 \times 10^{4}$ overnight. The following day, media was removed and replaced with serum-free DMEM for $2 \mathrm{~h}$ before cells were treated with $\mathrm{H}_{2} \mathrm{O}_{2}$ and lysed with $150 \mu \mathrm{l}$ of lysis buffer. ${ }^{7}$ Cell lysate was prepared and $80 \mu \mathrm{g}$ was analyzed on $10 \%$ SDS gels. For $\mathrm{H}_{2} \mathrm{O}_{2}$-induced senescence, cells were plated in 6-well plates overnight, and treated with $\mathrm{H}_{2} \mathrm{O}_{2}$ for 4 days. Following treatment, cells were passaged into fresh medium for $24 \mathrm{~h}$ and subcultured at low confluency for 10 days. Cells were stained as described, ${ }^{51}$ and positive cells were counted by light microscopy.

\section{SA- $\beta$ gal staining of MMTV-H-Ras mammary glands}

Mammary glands were immediately sliced into small pieces $(0.5 \mathrm{~cm} \times 0.5$ $\mathrm{cm}$ ) and snap frozen in liquid N2 after collection. Tissue pieces were fixed in glutaraldehyde $\mathrm{o} / \mathrm{n}$ before incubation in $\beta$-gal solution $\mathrm{o} / \mathrm{n}$, embedded in paraffin, and processed for histological analysis.

\section{Virus production}

Phoenix cells were plated at $0.4 \times 10^{6}$ in $6 \mathrm{~cm}$ dishes in DMEM overnight for retrovirus production of Flag-MKP1/5 in pQCXIP (WT and mutant). Cells were transfected with MKP constructs, VSV-G and gagPol expressing plasmids using FuGENE 6 (as stated above). MCF-7 cells were infected with filtered retroviral supernatant with addition of $8 \mu \mathrm{g} / \mathrm{ml}$ polybrene for $4-6 \mathrm{~h}$ before selection in puromycin. To make shPrdx1 lentivirus, 293T/17 (ATCC) cells were plated as above. The following day, cells were transfected with $1 \mu \mathrm{g}$ of either shPrdx1 or empty vector pLKO.1 with pDM2.G and psPAX2 expressing plasmids. Twenty-four hour virus was harvested and filtered, and cells were infected overnight. The following day, virus was removed and replaced with appropriate medium. Cells were selected with puromycin and checked for knockdown by SDS-PAGE/western blotting.

\section{CONFLICT OF INTEREST}

The authors declare no conflict of interest.

\section{ACKNOWLEDGEMENTS}

We would like to thank Dr Eisuke Nishida for providing the MKP-5 cDNA; Dr Yusen Liu for providing MKP-1 WT and MKP-1 C258S CDNA; and Dr Steve Rosenzweig and Dr Scott Eblen for fruitful discussions. This work has been funded by K22 ES01298501 (CAN), W81XWH-07-1-0691 (CAN), R01 CA131350, CCSG P30 CA138313 (HCC) and 5T32CA119945-05 (BT).

\section{REFERENCES}

1 Rhee SG. Cell signaling. H2O2, a necessary evil for cell signaling. Science 2006; 312: 1882-1883.

2 Claiborne A, Yeh JI, Mallett TC, Luba J, Crane 3rd EJ, Charrier V et al. Proteinsulfenic acids: diverse roles for an unlikely player in enzyme catalysis and redox regulation. Biochemistry 1999; 38: 15407-15416.

3 Neumann CA, Fang Q. Are peroxiredoxins tumor suppressors? Curr Opin Pharmacol 2007; 7: 375-380.

4 Neumann CA, Cao J, Manevich Y. Peroxiredoxin 1 and its role in cell signaling. Cell Cycle 2009; 8: 4072-4078.

5 Kim YJ, Lee WS, Ip C, Chae HZ, Park EM, Park YM. Prx1 suppresses radiationinduced c-Jun $\mathrm{NH} 2$-terminal kinase signaling in lung cancer cells through interaction with the glutathione S-transferase $\mathrm{Pi} / \mathrm{c}$-Jun $\mathrm{NH}$-terminal kinase complex. Cancer Res 2006; 66: 7136-7142.

6 Neumann CA, Wen ST, Van Etten RA. Role of the c-Abl tyrosine kinase in the cellular response to oxidative stress. Blood 1998; 92.

7 Cao J, Schulte J, Knight A, Leslie NR, Zagozdzon A, Bronson R et al. Prdx1 inhibits tumorigenesis via regulating PTEN/AKT activity. EMBO J 2009; 28: 1505-1517.

$8 \mathrm{Han}$ J, Sun P. The pathways to tumor suppression via route p38. Trends Biochem Sci 2007; 32: 364-371.

9 Wang W, Chen JX, Liao R, Deng Q, Zhou JJ, Huang S et al. Sequential activation of the MEK-extracellular signal-regulated kinase and MKK3/6-p38 mitogen-activated protein kinase pathways mediates oncogenic ras-induced premature senescence. Mol Cell Biol 2002; 22: 3389-3403.

10 Tonks NK. Protein tyrosine phosphatases: from genes, to function, to disease. Nat Rev Mol Cell Biol 2006; 7: 833-846.

11 Peters $\mathrm{GH}$, Frimurer $\mathrm{TM}$, Olsen $\mathrm{OH}$. Electrostatic evaluation of the signature motif $(H / V) C X 5 R(S / T)$ in protein-tyrosine phosphatases. Biochemistry 1998; 37: 5383-5393.

12 Tonks NK. Redox redux: revisiting PTPs and the control of cell signaling. Cell 2005; 121: $667-670$

13 Kamata H, Honda S, Maeda S, Chang L, Hirata H, Karin M. Reactive oxygen species promote TNFalpha-induced death and sustained JNK activation by inhibiting MAP kinase phosphatases. Cell 2005; 120: 649-661.

14 Neumann CA, Krause DS, Carman CV, Das S, Devendra D, Abraham JL et al. Essential role for the peroxiredoxin Prdx1 in erythrocyte antioxidant defense and tumor suppression. Nature 2003; 424: 561-565.

15 Todaro GJ, Green H. Quantitative studies of the growth of mouse embryo cells in culture and their development into established lines. J Cell Biol 1963; 17: 299-313.

16 Iwasa H, Han J, Ishikawa F. Mitogen-activated protein kinase p38 defines the common senescence-signalling pathway. Genes Cells 2003; 8: 131-144.

17 Bowers RR, Manevich Y, Townsend DM, Tew KD. Sulfiredoxin redox-sensitive interaction with S100A4 and non-muscle myosin IIA regulates cancer cell motility. Biochemistry 2012; 51: 7740-7754.

18 Jeong DG, Yoon TS, Kim JH, Shim MY, Jung SK, Son JH et al. Crystal structure of the catalytic domain of human MAP kinase phosphatase 5: structural insight into constitutively active phosphatase. J Mol Biol 2006; 360: 946-955.

19 Han YH, Kim H, Kim J, Kim S, Yu D, Moon EY. Inhibitory role of peroxiredoxin II (PrxIl) on cellular senescence. FEBS 2005; 579: 4897-4902.

20 Kuilman T, Michaloglou C, Mooi WJ, Peeper DS. The essence of senescence. Genes Dev 2010; 24: 2463-2479.

21 Rodier F, Coppe JP, Patil CK, Hoeijmakers WA, Munoz DP, Raza SR et al. Persistent DNA damage signalling triggers senescence-associated inflammatory cytokine secretion. Nat Cell Biol 2009; 11: 973-979.

22 Coulthard LR, White DE, Jones DL, McDermott MF, Burchill SA. p38(MAPK): stress responses from molecular mechanisms to therapeutics. Trends Mol Med 2009; 15: 369-379.

23 Trost TM, Lausch EU, Fees SA, Schmitt S, Enklaar T, Reutzel D et al. Premature senescence is a primary fail-safe mechanism of ERBB2-driven tumorigenesis in breast carcinoma cells. Cancer Res 2005; 65: 840-849. 
24 Lee JJ, Lee JH, Ko YG, Hong SI, Lee JS. Prevention of premature senescence requires JNK regulation of $\mathrm{BCl}-2$ and reactive oxygen species. Oncogene 2009; 29: 561-575.

25 Schilder YD, Heiss EH, Schachner D, Ziegler J, Reznicek G, Sorescu D et al. NADPH oxidases 1 and 4 mediate cellular senescence induced by resveratrol in human endothelial cells. Free Radic Biol Med 2009; 46: 1598-1606.

26 Weyemi U, Lagente-Chevallier O, Boufraqech M, Prenois F, Courtin F, Caillou B et al. ROS-generating NADPH oxidase NOX4 is a critical mediator in oncogenic H-Ras-induced DNA damage and subsequent senescence. Oncogene 2011; 31 1117-1129.

27 Dolado I, Swat A, Ajenjo N, De Vita G, Cuadrado A, Nebreda AR. p38alpha MAP kinase as a sensor of reactive oxygen species in tumorigenesis. Cancer Cell 2007; 11: 191-205.

28 Cross JV, Templeton DJ. Regulation of signal transduction through protein cysteine oxidation. Antioxid Redox Signal. [Review] 2006; 8: 1819-1827.

29 Hou N, Torii S, Saito N, Hosaka M, Takeuchi T. Reactive oxygen species-mediated pancreatic beta-cell death is regulated by interactions between stress-activated protein kinases, p38 and c-Jun N-terminal kinase, and mitogen-activated protein kinase phosphatases. Endocrinology 2008; 149: 1654-1665.

30 Nonn L, Duong D, Peehl DM. Chemopreventive anti-inflammatory activities of curcumin and other phytochemicals mediated by MAP kinase phosphatase- 5 in prostate cells. Carcinogenesis 2007; 28: 1188-1196.

31 Tephly LA, Carter AB. Differential expression and oxidation of MKP-1 modulates TNF-alpha gene expression. Am J Respir Cell Mol Biol 2007; 37: 366-374.

32 Dasgupta J, Kar S, Liu R, Joseph J, Kalyanaraman B, Remington SJ et al. Reactive oxygen species control senescence-associated matrix metalloproteinase-1 through c-Jun-N-terminal kinase. J Cell Physiol 2010; 225: 52-62.

33 Bar-Shira A, Rashi-Elkeles S, Zlochover L, Moyal L, Smorodinsky NI, Seger R et al. ATM-dependent activation of the gene encoding MAP kinase phosphatase 5 by radiomimetic DNA damage. Oncogene 2002; 21: 849-855.

34 Wang Z, Cao N, Nantajit D, Fan M, Liu Y, Li JJ. Mitogen-activated protein kinase phosphatase-1 represses c-Jun $\mathrm{NH} 2$-terminal kinase-mediated apoptosis via NF-kappaB regulation. J Biol Chem 2008; 283: 21011-21023.

35 Staples CJ, Owens DM, Maier JV, Cato AC, Keyse SM. Cross-talk between the p38alpha and JNK MAPK pathways mediated by MAP kinase phosphatase- 1 determines cellular sensitivity to UV radiation. J Biol Chem 2010; 285: 25928-25940.

36 Tephly LA, Carter AB. Differential expression and oxidation of MKP-1 modulates TNF-alpha gene expression. Am J Respir Cell Mol Biol 2007; 37: 366-374.

37 Dasgupta J, Kar S, Liu R, Joseph J, Kalyanaraman B, Remington SJ et al. Reactive oxygen species control senescence-associated matrix metalloproteinase-1 through c-Jun-N-terminal kinase. J Cell Physiol 2010; 225: 52-62.

38 Hutter D, Chen P, Barnes J, Liu Y. Catalytic activation of mitogen-activated protein (MAP) kinase phosphatase- 1 by binding to p38 MAP kinase: critical role of the p38 C-terminal domain in its negative regulation. Biochem $J$ 2000; 352(Pt 1): $155-163$

39 Slack DN, Seternes OM, Gabrielsen M, Keyse SM. Distinct binding determinants for ERK2/p38alpha and JNK map kinases mediate catalytic activation and substrate selectivity of map kinase phosphatase-1. J Biol Chem 2001; 276: 16491-16500.
40 Tanoue $T$, Maeda R, Adachi M, Nishida E. Identification of a docking groove on ERK and p38 MAP kinases that regulates the specificity of docking interactions. EMBO J 2001; 20: 466-479.

41 Day AM, Brown JD, Taylor SR, Rand JD, Morgan BA, Veal EA. Inactivation of a peroxiredoxin by hydrogen peroxide is critical for thioredoxin-mediated repair of oxidized proteins and cell survival. Mol Cell 2012; 45: 398-408.

42 Coppe JP, Patil CK, Rodier F, Krtolica A, Beausejour CM, Parrinello S et al. A humanlike senescence-associated secretory phenotype is conserved in mouse cells dependent on physiological oxygen. PLoS ONE 2010; 5: e9188.

43 Nonn L, Peng L, Feldman D, Peehl DM. Inhibition of p38 by vitamin D reduce interleukin-6 production in normal prostate cells via mitogen-activated protein kinase phosphatase 5 : implications for prostate cancer prevention by vitamin $D$. Cancer Res 2006; 66: 4516-4524.

44 Zhou JY, Liu Y, Wu GS. The role of mitogen-activated protein kinase phosphatase1 in oxidative damage-induced cell death. Cancer Res 2006; 66: 4888-4894.

45 Tanoue T, Yamamoto T, Maeda R, Nishida E. A novel MAPK phosphatase MKP-7 acts preferentially on JNK/SAPK and p38 alpha and beta MAPKs. J Biol Chem 2001; 276: 26629-26639.

46 Schindler EM, Hindes A, Gribben EL, Burns CJ, Yin Y, Lin MH et al. p38delta mitogen-activated protein kinase is essential for skin tumor development in mice. Cancer Res 2009; 69: 4648-4655.

47 Parra E, Ferreira J. Knockdown of the c-Jun-N-terminal kinase expression by siRNA inhibits MCF-7 breast carcinoma cell line growth. Oncol Rep 2010; 24 1339-1345.

48 Liu Y, Gorospe M, Yang C, Holbrook NJ. Role of mitogen-activated protein kinase phosphatase during the cellular response to genotoxic stress. Inhibition of c-Jun $\mathrm{N}$-terminal kinase activity and AP-1-dependent gene activation. J Biol Chem 1995; 270: 8377-8380.

49 Debnath J, Muthuswamy SK, Brugge JS. Morphogenesis and oncogenesis of MCF-10A mammary epithelial acini grown in three-dimensional basement membrane cultures. Methods 2003; 30: 256-268.

50 Dasari A, Bartholomew JN, Volonte D, Galbiati F. Oxidative stress induces premature senescence by stimulating caveolin-1 gene transcription through p38 mitogen-activated protein kinase/Sp1-mediated activation of two GC-rich promoter elements. Cancer Res 2006; 66: 10805-10814.

51 Dimri GP, Lee X, Basile G, Acosta M, Scott G, Roskelley C et al. A biomarker that identifies senescent human cells in culture and aging skin in vivo. PNAS 1995; 92: 9363-9367.

52 Wang Z, Cao N, Nantajit D, Fan M, Liu Y, Li JJ. Mitogen-activated protein kinase phosphatase-1 represses c-Jun $\mathrm{NH}_{2}$-terminal kinase-mediated apoptosis via NF-kappaB regulation. J Biol Chem 2008; 283: 21011-21023.

53 Theodosiou A, Smith A, Gillieron C, Arkinstall S, Ashworth A. MKP5 a new member of the MAP kinase phosphatase family, which selectively dephosphorylates stressactivated kinases. Oncogene 1999; 18: 6981-6988.

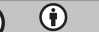

This work is licensed under a Creative Commons Attribution 3.0 Unported License. To view a copy of this license, visit http:// creativecommons.org/licenses/by/3.0/

Supplementary Information accompanies the paper on the Oncogene website (http://www.nature.com/onc) 